\section{(6)} OPEN ACCESS

\title{
Tolerising cellular therapies: what is their promise for autoimmune disease?
}

\author{
Chijioke H Mosanya, ${ }^{1,2}$ John D Isaacs ${ }^{1,2}$
}

\section{Handling editor Josef $S$ Smolen}

${ }^{1}$ Institute of Cellular Medicine, Faculty of Medical Sciences, Newcastle University, Newcastle upon Tyne, UK

${ }^{2}$ Musculoskeletal Unit, Newcastle upon Tyne Hospitals NHS Foundation Trust, Newcastle upon Tyne, UK

Correspondence to John D Isaacs, Institute of Cellular Medicine, Faculty of Medical Sciences, Newcastle upon Tyne NE2 4HH, UK; john.isaacs@ncl.ac.uk

Received 30 June 2018 Revised 22 September 2018 Accepted 6 October 2018 Published Online First 2 November 2018

\section{Check for updates}

(C) Author(s) (or their employer(s)) 2019. Re-use permitted under CC BY. Published by BMJ.

To cite: Mosanya $\mathrm{CH}$, Isaacs JD. Ann Rheum Dis 2019;78:297-310.

\section{ABSTRACT}

The current management of autoimmunity involves the administration of immunosuppressive drugs coupled to symptomatic and functional interventions such as antiinflammatory therapies and hormone replacement. Given the chronic nature of autoimmunity, however, the ideal therapeutic strategy would be to reinduce self-tolerance before significant tissue damage has accrued. Defects in, or defective regulation of, key immune cells such as regulatory $T$ cells have been documented in several types of human autoimmunity. Consequently, it has been suggested that the administration of ex vivo generated, tolerogenic immune cell populations could provide a tractable therapeutic strategy. Several potentially tolerogenic cellular therapies have been developed in recent years; concurrent advances in cell manufacturing technologies promise scalable, affordable interventions if safety and efficacy can be demonstrated. These therapies include mesenchymal stromal cells, tolerogenic dendritic cells and regulatory $T$ cells. Each has advantages and disadvantages, particularly in terms of the requirement for a bespoke versus an 'offthe-shelf' treatment but also their suitability in particular clinical scenarios. In this review, we examine the current evidence for these three types of cellular therapy, in the context of a broader discussion around potential development pathway(s) and their likely future role. A brief overview of preclinical data is followed by a comprehensive discussion of human data.

\section{INTRODUCTION}

The complexity of immune tolerance mechanisms presents abundant opportunities for its breakdown, leading to the development of autoimmunity. In most cases, the precise pathogenesis of autoimmunity remains unknown but the genetic polymorphisms that underpin, for example, rheumatoid arthritis (RA), indicate that antigen presentation, cytokine dysregulation and the regulation of lymphocyte activation all play key roles. Furthermore, the clustering of different autoimmune diseases within families attests to common genetic predisposition and pathogenic mechanisms. However, for most autoimmune diseases, the provoking autoantigen(s) have not been defined and, critically, the predilection for the joint in RA versus the brain in multiple sclerosis (MS) versus the pancreas in diabetes mellitus remains enigmatic. Ultimately, the immune system can be viewed as a delicate balance of activation vs tolerance, with multiple mechanisms acting to maintain homeostasis.

Historically, management of autoimmune disorders involved managing end-organ manifestations such as insulin replacement in diabetes and control of pain and inflammation in conditions such as RA (table 1). During the second half of the 20th century the discovery of glucocorticoids and, subsequently, immunosuppressant medications enabled modification of the autoreactive process with reduced tissue damage and even improved life expectancy in diseases such as systemic lupus erythematosus (SLE). The 21st century has seen the biologics revolution with potent, targeted therapies that neutralise key proinflammatory cytokines or interfere with lymphocytes themselves. And, most recently, potent synthetic signalling pathway inhibitors are providing a further means to modulate immune reactivity. ${ }^{1}$ Nonetheless, current management options rarely lead to cure, or drug-free remission, and most patients require long-term maintenance therapy to control disease manifestations. For example, in RA, approximately $30 \%$ of patients achieve sustained remission, but $50 \%$ of these will flare if treatment is discontinued. The proportion that flare is usually higher once patients have moved on to more potent biological therapies. ${ }^{2}$ Because immunosuppressants downregulate the normal adaptive immune system, it is not surprising that several of the therapies in table 1 are associated with an enhanced infection risk, including opportunistic infections, and the development of malignancy. This is in addition to disease comorbidities and drug-specific side-effects, for example, with chronic glucocorticoids. In extreme cases, haematopoietic stem cell transplantation has been used to treat autoimmunity but, with rare exceptions, this intervention has not proved curative. ${ }^{34}$

The holy grail of treatment for autoimmunity would be the reinstatement of immune tolerance. So-called therapeutic tolerance induction offers the opportunity to 'reset' the diseased immune system to a state of immune tolerance, theoretically providing for long-term, drug-free remission. ${ }^{5}$ While multiple strategies have proven effective in animal models of autoimmunity and transplantation, translation to the clinic has been slow. Multiple explanations have been offered, relating to disease stage, therapeutics employed, and the need for better biomarkers of tolerance, among others. Nonetheless, because of the slow progress with therapeutics that target the immune system, such as biologic drugs and peptides, recent strategies have focused on the use of tolerogenic cells themselves.

\section{TOLEROGENIC CELL TYPES}

In recent years, investigators have turned their attention to the ex-vivo expansion or differentiation of 'tolerogenic' immune cells, followed by their adoptive transfer, as a potential route to therapeutic tolerance induction. To a large degree, these strategies have been catalysed by advances in bio-manufacturing in general, with robust and scalable processes leading to the efficient manufacture of advanced cellular 


\begin{tabular}{ll}
\hline Table 1 Current therapeutic options for management of autoimmunity & \\
\hline Therapy & Mode of action \\
\hline Insulin, thyroxine, etc. & Replacement therapy \\
\hline Paracetamol, opiates & Analgesia \\
\hline Non-steroidal anti-inflammatory drugs: aspirin, ibuprofen, diclofenac, naproxen, etc. & Anti-inflammatory \\
\hline COX-2 inhibitors: celecoxib, etc. & Anti-inflammatory \\
\hline Glucocorticoids: prednisolone, prednisone, dexamethasone, etc. & Anti-inflammatory, immunosuppressive \\
DMARDS: MTX, sulphasalazine, leflunomide, hydroxychloroquine, azathioprine, & Various, generally not well defined. Anti-inflammatory, immunosuppressive, possibly \\
mycophenolate mofetil, ciclosporin, etc. & immunomodulatory. Some, such as MTX, may have more than one mode of action. \\
\hline Cytokine blockade (anti-TNF, anti-IL6 receptor) & Anti-inflammatory and immunosuppressive, immunomodulatory \\
\hline B-cell depletion/modulation (anti-CD20, anti-BLyS) & Immunosuppressive, immunomodulatory \\
\hline Costimulation blockade (abatacept) & Immunosuppressive, immunomodulatory \\
\hline Janus kinase inhibitors (tofacitinib, baricitinib, others in development) & Anti-inflammatory, immunosuppressive, immunomodulatory \\
\hline Intravenous immunoglobulins & Immunomodulatory (via Fc receptor interactions) \\
\hline Plasmapheresis & Immunosuppressive, immunomodulatory (by removing (auto)antibodies and other \\
\hline
\end{tabular}

For several therapies, particularly DMARDs, the precise mode of action is not known. Immunomodulation denotes that the treatment has a specific and defined effect on the immune system.

DMARDs, disease-modifying anti-rheumatic drugs; MTX, methotrexate.

therapies. ${ }^{6}$ To date, three main types of tolerogenic cell have been the focus of therapeutic strategies in humans.

\section{Mesenchymal stromal cells}

Mesenchymal stromal cells (MSCs) are spindle-shaped, plastic-adherent, progenitor cells of mesenchymal tissues with multipotent differentiation capacity. ${ }^{7}$ MSCs can modulate innate and adaptive immune cells including dendritic cells (DC), natural killer cells (NK) cells, macrophages, B-lymphocytes and T-lymphocytes. This occurs via both cell-cell contact and paracrine interactions through several soluble mediators including indoleamine-2,3-dioxygenase (IDO), prostaglandin E2 and transforming growth factor $\beta .^{8-10}$ These and other mechanisms have been summarised in figure 1. By definition, MSCs can differentiate into bone, chondrocytes and adipose tissue in vitro; they are phenotypically positive for CD105, CD73 and CD90 and negative for haematopoietic markers CD45, CD34, CD14, CD11b, CD3 and CD19. ${ }^{71}$ They do not express Class II MHC molecules unless stimulated by interferons ${ }^{7}$ and lack costimulatory molecules such as CD40, CD80 and CD86.

Exposure to proinflammatory cytokines IFN- $\gamma$, TNF and IL-1 $\beta^{10}$ and activation by exogenous/endogenous danger signals such as bacterial products and heat shock proteins through Toll-like receptor 3 (TLR3) 'licenses' MSCs to become immunosuppressive ${ }^{12}$; in contrast, activation through TLR4 confers a proinflammatory signature and, under some conditions, TLR3 signals may do the same. ${ }^{12} 13$ The immunomodulatory functions of MSC include their ability to: inhibit T cell proliferation and promote their differentiation into regulatory $\mathrm{T}$ cells (Tregs) $;^{14}$ inhibit the $\mathrm{CD} 4^{+} \mathrm{T}$ cell induced differentiation of B-cells into plasma cells and directly inhibit B-cell proliferation, differentiation and chemotaxis. ${ }^{15}$ Although MSCs reside in most postnatal organs and tissues, ${ }^{16}$ they are readily harvested from bone marrow, adipose tissues, umbilical cord blood and Wharton's jelly (figure 2).

\section{Tolerogenic dendritic cells (tolDC)}

DCs are best recognised for their antigen presenting functions in driving immune responses against pathogens and tumour cells. However, DC also play crucial roles in co-ordinating central and peripheral tolerance processes, such that absent or deficient DC associate with an increased tendency to develop autoimmunity. ${ }^{17} 18$
Furthermore, in autoimmunity, DC are skewed to a proinflammatory state, producing more proinflammatory cytokines and leading to activation and differentiation of autoreactive T cells. ${ }^{19}$

Immature DC are usually regarded as tolerogenic, whereas mature DC can exert either tolerogenic or immunogenic functions depending on signals received during maturation from the microenvironment and invading pathogens. For instance, bacterial lipopolysaccharides induce immunogenic maturation of DC by upregulating surface MHC complexes and T cell costimulatory molecules (CD80, CD86), ${ }^{20}{ }^{21}$ while schistosomal lysophosphatidylserine, anti-inflammatory cytokines (eg, IL-10) and glucocorticoids induce a tolerogenic phenotype. ${ }^{18}$ Tolerogenic dendritic cells (tolDC) induce peripheral tolerance by induction of anergy and deletion of T cells, ${ }^{22}$ blockade of T cell expan$\operatorname{sion}^{23}$ and induction of regulatory $\mathrm{T}$ cells (Tregs). ${ }^{24} 25$ Tregs in turn induce the regulatory properties of DC (figure 1). These mechanisms have already been reviewed. ${ }^{2627}$

Several methods can be used to produce stable tolDC ex vivo, with limited or no capacity to transdifferentiate into immunogenic DC. Common methods include inhibiting the expression of immune-stimulatory molecules (CD80/CD86 and IL-2) 28-30 $^{28}$ or stimulating constitutive expression of immunosuppressive molecules such as IL-4, IL-10 and CTLA-4, ${ }^{31-35}$ through genetic engineering. Also, exposing differentiating DC ex-vivo to drugs such as dexamethasone and vitamin $\mathrm{D} 3^{36}{ }^{37}$ or immunosuppressive cytokines such as IL-10 and TGF- $\beta^{38-40}$ and lipopolysaccharides $^{41}$ can be used to produce tolDC. These and other methods have been extensively reviewed elsewhere. ${ }^{42}$

\section{Regulatory T cells (Tregs)}

Tregs are a subset of $\mathrm{T}$ cells expressing CD4, CD25 and intracellular Forkhead Box P3 (FoxP3) protein that inhibit the functions of effector $\mathrm{T}$ cells as well as other immune effector cells and so are essential for immune tolerance. ${ }^{43} 44$ They mediate their effects by producing immunosuppressive cytokines and by cell-to-cell contact, following stimulation via their antigen-specific $\mathrm{T}$ cell receptors (TCR). These mechanisms also modulate other immune responses in an antigen-non-specific manner through 'bystander suppression' and 'infectious tolerance'. ${ }^{45} 46$ Treg depletion and dysfunction have been implicated in a variety of autoimmune disorders including type 1 diabetes, RA, SLE and, classically, with an 


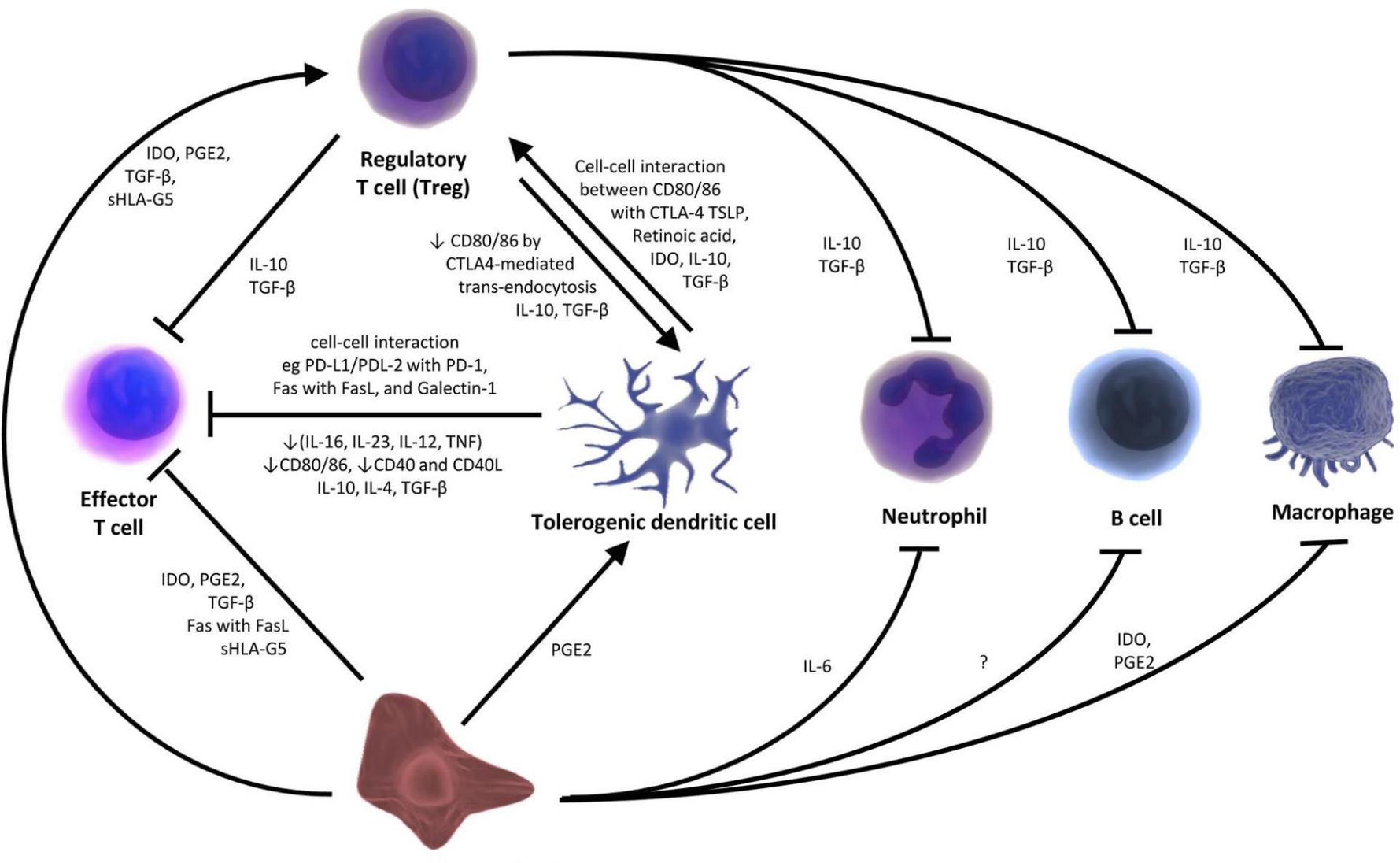

Mesenchymal stromal cell

Figure 1 A schematic representation of the mechanisms of action of tolerogenic cells. MSCs promote the differentiation and survival of Tregs and tolDC. Tregs and toIDC, on the other hand, enjoy a mutual bidirectional positive interaction with each other. Tregs and MSCs inhibit the actions of $B$ cells, effector T cells, macrophages and neutrophils through cell-cell contact (eg, Fas:Fas Ligand (FasL) mediated deletion), and various soluble factors such as TGF- $\beta$, IDO, PGE2, IL-10, IL-6, and sHLA-G5. MSCs also act through extracellular vesicles. ${ }^{8-10} 18$ TolDC directly inhibit effector T cells through various mechanisms. These include: cell-cell ligand-receptor mediated deletion, for example, Fas: FASL, PD-L1 and PD-L2 on tolDC and PD-1 receptors on effector T cells; effector T cell anergy secondary to low expression of co-stimulatory molecules CD80/CD86, CD40 and pro-inflammatory cytokines (TNF, IL-12, IL-21 and IL-16) by tolDC. Other mechanisms include soluble anti-inflammatory cytokines such as IL-10, IL-4 and TGF- $\beta{ }^{26}{ }^{27}$ TolDC directly promote Tregs and so indirectly inhibit other immunogenic cells through Tregs. Mechanisms include soluble factors such as IL-10, IDO, TGF- $\beta$ and TSLP and cell-cell interaction between CTLA-4 and CD80/86. This interaction, in turn, leads to transendocytosis of CD80/86 and further tolerogenic phenotypic 'reinforcement' of tolDC. Tregs also promote tolDC via IL-10 and TGF- $\beta .{ }^{2627}$ CTLA-4, cytotoxic T-lymphocyte associated protein 4; IDO, indoleamine-2,3-dioxygenase; IL, interleukin; MSCs, mesenchymal stromal cells; PDL, programmed death ligand; PGE2, prostaglandin E2; sHLA, soluble human leucocyte antigen; TGF- $\beta$, transforming growth factor beta; toIDC, tolerogenic dendritic cells; TSLP, thymic stromal lymphopoietin.

inherited deficiency of FoxP3, immune dysregulation polyendocrinopathy enteropathy X linked syndrome. ${ }^{47} 48$ These findings support the possibility that ex-vivo expansion and transfusion of autologous or allogeneic Tregs could provide an effective therapeutic strategy for unwanted immunopathology such as autoimmunity.

In the past, the lack of reliable Treg surface markers and the resultant possibility of simultaneously isolating and transfusing proinflammatory $\mathrm{T}$ cells slowed the development of protocols for Treg isolation and expansion. ${ }^{5}$ More recent studies have used $\mathrm{CD} 4, \mathrm{CD} 25$ and $\mathrm{CD} 127$ cell surface markers to isolate $\mathrm{CD} 4{ }^{+} \mathrm{C}$ D127 $7^{10 /} \mathrm{CD} 25^{+}$Tregs from blood. ${ }^{49}{ }^{50}$ Other types of regulatory T cells exist, such as T-regulatory type $1(\operatorname{Tr} 1)$ cells, which secrete IL-10. ${ }^{51}$ These are a distinct population of regulatory $\mathrm{T}$ cells that only transiently express FoxP3, on activation. ${ }^{52}$ They coexpress CD49b and LAG-3, and secrete high levels of IL-10 but low amounts of IL-4 and IL-17. Suppression is dependent on IL-10 and TGF- $\beta$ and they kill myeloid antigen-presenting cells via granzyme $B$ release.

\section{Migration of tolerogenic cells}

MSCs, Tregs and tolDC express a host of homing receptors that are important for their transmigration from the tissue of administration (eg, skin or vascular system) to activation sites (eg, regional lymph nodes) and, ultimately, to the target organs. For instance, FoxP3 + Tregs express CC receptor 7 (CCR7), CCR4, CCR6, CXC receptor 4 (CXCR4) and CXCR5. They also express CD103 (integrin $\alpha_{\mathrm{F}} \beta_{7}$ ) (whose ligand is E-cadherin expressed by epithelial cells) and CD62L (L-selectin) (whose ligands are the lymph node and mucosal lymphoid tissue endothelial cell addressins CD34, GlyCAM-1 and MAdCAM-1). ${ }^{53}$ Activated tolDC express CCR7 and migrate to CC chemokine ligand 19 (CCL19), ${ }^{54}$ underpinning migration to regional lymph nodes. MSCs, on the other hand, express a restricted set of chemokine receptors (CXCR4, CX3CR1, CXCR6, CCR1, CCR7) and have shown appreciable chemotactic migration in response to the chemokines CXC ligand 12 (CXCL12), CX3CL1, CXCL16, CCL3 and CCL19. ${ }^{55}$ MSCs may also exert tolerogenic effects in distant tissues via extracellular vesicles. ${ }^{10}$ It is clearly important that migration potential is considered during the generation of cellular therapies. 


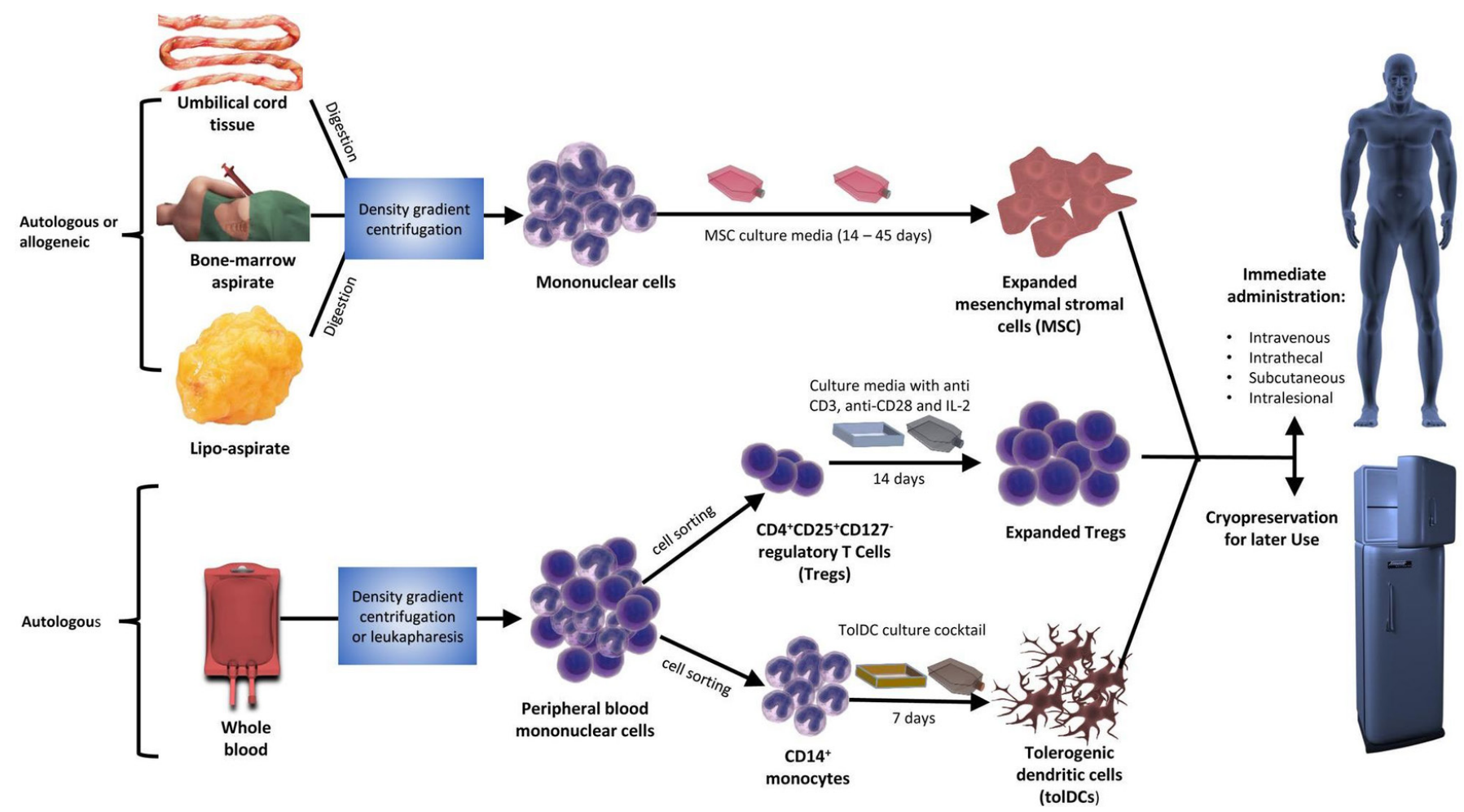

Figure 2 Preparation and administration of tolerogenic cellular therapies. This figure describes the process of cellular therapy manufacture and administration. Sources of substrate cells include autologous or allogeneic umbilical cord tissue, bone marrow aspirate and lipo-aspirate for mesenchymal stromal cells and autologous whole blood for expanded regulatory T cells and tolerogenic dendritic cells. Mononuclear cells are usually extracted by density gradient centrifugation of whole blood, bone marrow aspirate and digested tissue (lipo-aspirate and umbilical cord tissue) or by leukapheresis (whole blood). Mononuclear cells are then cultured in the appropriate media and culture conditions for the requisite duration or number of passages. Harvested cells can be administered immediately through various routes (subcutaneous, intravenous, intralesional and intrathecal) or cryopreserved for future use.

\section{CELLULAR THERAPIES FOR THERAPEUTIC TOLERANCE What could cellular therapies achieve?}

Numerous preclinical studies using animal models of autoimmune disorders have shown potent tolerogenic effects of these various immune modulatory cells, although some mechanisms of action remain unclear. Animal models do not faithfully replicate all mechanisms of human autoimmunity but positive results have provided the scientific basis to catalyse clinical trials.

\section{Mesenchymal stromal cells (MSCs)}

The first ever preclinical study of MSCs in an autoimmune setting was in experimental auto-immune encephalomyelitis (a model for MS). ${ }^{56}$ MSCs were effective in treating the disease and were shown to be strikingly effective if injected before or at the onset of disease. Further studies in experimental MS buttressed this finding ${ }^{57-60}$ and showed that MSCs control disease through inhibition of $\mathrm{CD} 4{ }^{+} \mathrm{Th} 17 \mathrm{~T}$ cells, ${ }^{58}$ generation of $\mathrm{CD} 4{ }^{+} \mathrm{CD} 25^{+-}$ FoxP $3^{+}$Tregs $^{60}$ and through hepatocyte growth factor production. ${ }^{59}$ Therapeutic efficacy was also observed in the MRL/Lpr ${ }^{61}$ and NZB/W F1 ${ }^{62}{ }^{63}$ mouse models of SLE. MSCs were effective in collagen-induced arthritis, ${ }^{6465}$ Freund's adjuvant-induced arthritis and $\mathrm{K} / \mathrm{BxN}$ mice with spontaneous erosive arthritis. ${ }^{66}$ These studies have been reviewed elsewhere. ${ }^{10}$

Results from early clinical trials in MS showed good tolerability and some potential efficacy ${ }^{67-70}$ (table 2A) associated with increased number of Tregs in the peripheral blood of patients. ${ }^{67}$ In the most recent controlled study, ${ }^{70} 13$ patients received MSCs while 10 patients received conventional MS treatment. The active treatment group showed a more stable disease course and a transient increase in immunomodulatory cytokines. A placebo-controlled dose-ranging study of mesenchymal-like cells derived from placenta in patients with $\mathrm{MS}^{71}$ used a distinct type of cell with immunomodulatory and regenerative properties, which do not fully meet ISCT criteria for MSCs (and therefore not included in table 2A). Their phenotype includes CD10+, CD105+ and CD200+; they are CD34- and, like MSCs, do not express class II HLA or costimulatory molecules CD80, CD86. The cells appeared safe and well tolerated in patients with relapsing remitting MS and secondary progressive MS.

In RA, MSCs were well-tolerated and showed preliminary efficacy with improvements in clinical outcomes when combined with disease-modifying anti-rheumatic drugs (DMARDS). ${ }^{72} 73 \mathrm{In}$ the first placebo-controlled randomised trial of MSCs in RA, ${ }^{73}$ 40 patients who had failed at least two biological DMARDS received intravenous infusions of adipose-derived MSCs at varying dose, while 7 patients received placebo. Adverse events were few and included fever and respiratory tract infections; however, serious adverse events included a lacunar infarction. Clinical outcomes, especially DAS28-ESR, showed a dose-dependent improvement.

The first case series of MSC in patients with SLE was published in $2009{ }^{74}$ Four patients with cyclophosphamide/glucocorticoid-refractory SLE were treated with bone marrow-derived MSCs. After 12-18 months of follow-up, all showed improvement in disease activity, renal function and serological markers. Subsequent studies, mainly by the same group, have confirmed that MSCs are safe in SLE and reported promising results such as improvement in renal function, proteinuria, SLE disease activity 
Table 2A Clinical trials of mesenchymal stromal cells in MS, RA and SLE

Number of patients, source of cells, dose and route of

\begin{tabular}{|c|}
\hline Diseases and clinical trials \\
\hline
\end{tabular}

\begin{tabular}{|c|c|c|c|}
\hline \multicolumn{4}{|l|}{ Multiple sclerosis, MS } \\
\hline $\begin{array}{l}\text { 1. Karussis et al }(2010)^{67} \\
\text { Phase I/II uncontrolled } \\
\text { feasibility study of patients } \\
\text { with MS and ALS }\end{array}$ & $\begin{array}{l}34 \text { patients ( } 15 \text { with MS, } 19 \text { with ALS) received autologous } \\
\text { BM-derived MSCs intrathecally ( } n=34) \text { at a mean dose of } \\
63.2 \times 10^{6} \text { in } 2 \mathrm{mls} \text { of saline and intravenously }(n=14) \text { at a } \\
\text { mean dose of } 23.4 \times 10^{6} \text { cells in } 2 \mathrm{mls} \text { of saline. }\end{array}$ & $\begin{array}{l}\text { No major AEs. EDSS score improved over } 6 \text { months. } \\
\text { Proportion of CD4 } 4^{+} C D 25^{+} \text {Tregs increased, and } \\
\text { expression of CD40, CD83, CD86 and HLA-DR } \\
\text { on myeloid dendritic cells decreased } 24 \text { hours } \\
\text { post-administration. MRI of MSC labelled with } \\
\text { superparamagnetic particles showed MSCs in } \\
\text { meninges, subarachnoid space, and spinal cord. }\end{array}$ & $\begin{array}{l}\text { No comparison between intravenous and } \\
\text { Intrathecal routes as regards homing of } \\
\text { MSCs to the CNS. Cryopreserved cells } \\
\text { were used. }\end{array}$ \\
\hline $\begin{array}{l}\text { 2. Bonab et al }(2012)^{68} \\
\text { Phase II uncontrolled study } \\
\text { of patients with SPMS }\end{array}$ & $\begin{array}{l}22 \text { patients received Intrathecal, autologous BM-derived } \\
\text { MSCs at a mean dose of } 29.5 \times 10^{6} \text { cells in } 10 \mathrm{mls} \text { of normal } \\
\text { saline. }\end{array}$ & $\begin{array}{l}\text { AEs were low-grade: transient fever, headache, } \\
\text { nausea/vomiting (related to lumbar puncture). } \\
\text { Disease progression stabilised in the short-term } \\
\text { evidenced by MRI and EDSS score. }\end{array}$ & $\begin{array}{l}\text { After initial improvement some patients } \\
\text { reported worsening EDSS, and about 25\% } \\
\text { showed worsening lesions on MRI, after } \\
12 \text { months. Cryopreservation was not } \\
\text { discussed. }\end{array}$ \\
\hline $\begin{array}{l}\text { 3. Connick et al }(2012)^{69} \\
\text { Phase lla feasibility/ proof- } \\
\text { of-concept study in patients } \\
\text { with SPMS }\end{array}$ & $\begin{array}{l}10 \text { patients received autologous bone marrow (BM)-derived } \\
\text { MSCs intravenously at a mean dose of } 1.6 \times 10^{6} \text { cells } / \mathrm{kg} \text {. }\end{array}$ & $\begin{array}{l}\text { Mild AEs such as transient post-transfusion rash and } \\
\text { self-limiting bacterial infections. Improvement in } \\
\text { visual acuity, visual evoked potentials, optic nerve } \\
\text { area and EDSS. No change in post-treatment T cell } \\
\text { subset counts. }\end{array}$ & Cryopreserved cells were used. \\
\hline $\begin{array}{l}\text { 4. Li et al }(2014)^{70} \\
\text { Randomised } \\
\text { Controlled Phase II study } \\
\text { in patients with RRMS and } \\
\text { SPMS }\end{array}$ & $\begin{array}{l}13 \text { patients received } 3 \text { cycles of intravenous, allogeneic } \\
\text { umbilical cord (UC)-derived MSCs, } 2 \text { weeks apart, at } \\
\text { a dose of } 4 \times 10^{6} \text { cells/kg body weight in } 100 \mathrm{mls} \text { of } \\
\text { saline. Conventional treatment (anti-inflammatory and } \\
\text { immunosuppressants) was continued; } 10 \text { patients received } \\
\text { only conventional treatment. }\end{array}$ & $\begin{array}{l}\text { Reduced frequency of recurrence in the treatment } \\
\text { group, who also had a more steady disease course. } \\
\text { No significant adverse event. Transient improvement } \\
\text { in immunomodulatory cytokines was recorded }\end{array}$ & $\begin{array}{l}\text { Randomised controlled study but not } \\
\text { blinded. Cryopreservation was not } \\
\text { discussed }\end{array}$ \\
\hline
\end{tabular}

Rheumatoid arthritis

$\begin{array}{ll}\begin{array}{l}\text { 5. Wang et al }(2013)^{72} \\ \text { Phase II non-randomised, } \\ \text { controlled study }\end{array} & \begin{array}{l}172 \text { patients with active RA. } 136 \text { received } 4 \times 10^{7} \text { allogeneic } \\ \text { UC-derived MSCs in 40mls of intravenous saline while } 36 \\ \text { received only saline. All patients continued their DMARDS. }\end{array} \\ \begin{array}{l}\text { 6. Alvaro-Gracia et al } \\ (2017)^{73}\end{array} & \begin{array}{l}53 \text { patients with refractory RA (failed two biologics) } \\ \text { received three intravenous infusions at different doses } \\ \left(1 \times 10^{6}, 2 \times 10^{6} \text { and } 4 \times 10^{6} \text { cells/kg) of allogeneic, adipose- }\right. \\ \begin{array}{l}\text { Dose-escalation, } \\ \text { randomised, single-blind } \\ \text { (double-blind for efficacy), }\end{array}\end{array}\end{array}$

No serious adverse events. TNF-alpha and IL- 6 decreased while Fox $\mathrm{P3}^{+}$Tregs increased in the treatment group after infusion. Better clinical outcomes (ACR responses, HAQ and DAS28) after 3 months in the treatment group

Generally well-tolerated. Mild adverse events. Dosedependent response especially DAS28-ESR at 1 month and 3 months post-infusion. Distribution of cell populations was not significantly modified.
Non-randomised study. Treatment group and control group were recruited in different time frames. Cryopreserved cells were used

First placebo-controlled study of MSCs in RA. $19 \%$ of patients generated mesenchymal stromal cell-specific antiHLA1 antibodies without apparent clinical consequences. Cryopreserved cells were used

phase $\mathrm{Ib} / \mathrm{lla}$ study

SLE

7. Sun et al (2009) ${ }^{74} \quad$ Four patients with refractory SLE received intravenous,

Safety of MSC in Patients allogeneic BM-derived MSCs at a dose of $1 \times 10^{6}$ cells $/ \mathrm{kg}$. with refractory SLE

8. Liang et al (2010) ${ }^{75} \quad 15$ patients with refractory SLE were treated with one

Early phase safety/efficacy intravenous infusion of $1 \times 10^{6}$ cells $/ \mathrm{kg}$ allogeneic BM-MSC.

study in refractory SLE

Mean follow-up period of 17.2 months

9. Sun et al $(2010)^{76}$

Early phase I/II study

16 patients with active and refractory SLE on different treatment regimens received $1 \times 10^{6}$ cells $/ \mathrm{kg}$ intravenous of UC-derived MSC

\section{Safe and well-tolerated. Stable course of SLE disease activity by 12-18 months post-treatment, with improvement in SLEDAI and serological markers. No serious adverse events. All patients clinically improved with decrease in SLEDAl, proteinuria, and anti-dsDNA. \\ Significant improvement in SLEDAI score autoantibodies, complement C3 and renal function accompanied by increased Tregs.}

First study in SLE. Provided evidence for further studies in SLE. Cryopreservation was not discussed.

Improvement in some patients allowed reduction in doses of steroids and immunosuppressants. Cryopreservation was not discussed.

Patients clinically improved despite reducing doses of maintenance steroids and immunosuppressants. Cryopreservation was not discussed.

10. Wang et al (2012) Early phase I/II study. Compared the efficacy of single and double infusions

11. Li et al (2013) ${ }^{78}$ Early phase I/II study in patients with SLE with refractory cytopaenia

58 patients with refractory and active SLE. 30 received one intravenous dose of $1 \times 10^{6}$ cells $/ \mathrm{kg}$ allogeneic BM-MSCs or UC-MSCs, while 28 received two infusions of $1 \times 10^{6}$ cells/

No remarkable difference in SLEDAI and serological $\mathrm{kg} 1$ week apart.

35 patients with SLE with refractory cytopaenia received

$1 \times 10^{6}$ cells $/ \mathrm{kg}$ of either allogeneic BM-derived or allogeneic UC-derived MSCs and followed up for an average of 21 months.

12. Wang et al (2013) $79 \quad 87$ patients with SLE . Allogeneic BM-MSC or UC-MSC

Early phase I/II 4 year single-centre study treated with cyclophosphamide to inhibit active lymphocyte response. 18 patients received repeat doses of MSC for relapses

13. Wang et al (2014) 40 patients with active and refractory SLE received Multicentre phase I/II study two intravenous doses of $1 \times 10^{6}$ cells $/ \mathrm{kg}$ allogeneic UC-derived MSCs while still maintaining baseline immunosuppressants+/-steroids. marker changes between the two groups. improvement between single and double dose cohorts may be related to sample size. Cryopreservation was not discussed.

Well-tolerated. Significant improvement in blood cell Focused on haematological parameters in counts after MSC treatment. Clinical improvement was also associated with increased Tregs and decreased Th17.

Generally safe and well-tolerated. SLEDAI score, renal function and blood counts significantly improved for up to 4 years. All patients underwent tapering of steroids and immunosuppressants according to clinical status.

Well-tolerated. $60 \%$ achieved major clinical response or partial clinical response as determined by BILAG scores. SLEDAI, renal function and serological indices also improved allowing tapering of steroid and immunosuppressant doses. pretreated with cyclophosphamide and regard to source of cells (UC and BM). Cryopreservation was not discussed.

$12.5 \%$ and $16.7 \%$ relapse rate at 9 and 12 months, respectively. Cryopreservation was not discussed

ACR, American College of Rheumatology; AE: adverse events; ALS, amyotrophic lateral sclerosis; BM, bone marrow; BILAG, British Isles Lupus Activity Group; DAS28, Disease Activity Score-28 joint count; EDSS, Expanded Disability Status Score; HAQ, Health Assessment Questionnaires; RA, rheumatoid arthritis; RRMS, relapsing remitting multiple sclerosis; SLEDAI, Systemic Lupus Erythematosus Disease Activity Index; SPMS, secondarily progressive multiple sclerosis; UC, umbilical cord. 


\begin{tabular}{|c|c|c|c|}
\hline Diseases and clinical trials & $\begin{array}{l}\text { Number of patients, source of cells, dose and } \\
\text { route of administration }\end{array}$ & Outcomes & Comments \\
\hline \multicolumn{4}{|l|}{ Crohn's disease } \\
\hline $\begin{array}{l}\text { 1. Garcia-Olmo et al }(2005)^{82} \\
\text { Phase I study }\end{array}$ & $\begin{array}{l}5 \text { patients with fistulating Crohn's disease received } \\
\text { intralesional injections of autologous adipose derived } \\
\text { at a dose of between } 3 \text { to } 30 \times 10^{6} \text { cells depending } \\
\text { on yield. }\end{array}$ & $\begin{array}{l}\text { Six out of eight fistulae healed completely after } 8 \\
\text { weeks. No adverse effects }\end{array}$ & $\begin{array}{l}\text { First clinical trial of mesenchymal stem } \\
\text { cells to treat Crohn's disease. Cells were } \\
\text { not cryopreserved. Study published before } \\
\text { the ISCT criteria for MSC was set so cells } \\
\text { were not assessed against the ISCT criteria. }\end{array}$ \\
\hline $\begin{array}{l}\text { 2. Garcia-Olmo et al }(2009)^{83} \\
\text { Phase II multicentre randomised } \\
\text { controlled trial }\end{array}$ & $\begin{array}{l}49 \text { patients with complex fistulae. } 24 \text { received } \\
\text { intralesional injection of } 20 \times 10^{6} \text { cells } / \mathrm{kg} \text { allogeneic } \\
\text { adipose derived stem cells; } 25 \text { received fibrin glue. }\end{array}$ & $\begin{array}{l}\text { Significantly better fistula healing in the treatment } \\
\text { group (relative risk } 4.43 \text { ). Quality of life scores } \\
\text { were also higher in the treatment group }\end{array}$ & \\
\hline $\begin{array}{l}\text { 3. Duijvestein et al }(2010)^{84} \\
\text { Phase I study }\end{array}$ & $\begin{array}{l}9 \text { patients with refractory Crohn's disease received } \\
\text { two IV infusions of } 1-2 \times 10^{6} \text { cells } / \mathrm{kg} \text { autologous BM- } \\
\text { derived MSCs } 7 \text { days apart. }\end{array}$ & $\begin{array}{l}\text { Well tolerated with few mild adverse events such } \\
\text { as allergic reaction in a patient. Three patients } \\
\text { showed improvement in Crohn's disease activity } \\
\text { indices } 6 \text { weeks post-treatment }\end{array}$ & $\begin{array}{l}\text { Three patients required surgery due to } \\
\text { worsening disease. }\end{array}$ \\
\hline $\begin{array}{l}\text { 4. Ciccocioppo et al (2011) } \\
\text { Phase I/II study in patients with } \\
\text { fistulating Crohn's disease }\end{array}$ & $\begin{array}{l}10 \text { patients with refractory Crohn's disease received } \\
\text { intralesional injection of autologous BM-derived MSCs } \\
\text { at a median dose of } 20 \times 10^{6} \text { cells every } 4 \text { weeks for } \\
\text { a median four cycles (injections were stopped when } \\
\text { patients achieved remission or exhausted supplies of } \\
\text { autologous MSCs). }\end{array}$ & $\begin{array}{l}\text { Clinical improvement in all patients with seven } \\
\text { achieving complete fistula closure and three } \\
\text { achieving partial closure. Few adverse events were } \\
\text { documented. Tregs also increased post-treatment } \\
\text { and remained stable post follow-up. }\end{array}$ & Cryopreserved cells were used \\
\hline $\begin{array}{l}\text { 5. Liang et al (2012) } \\
\text { Use of MSCs in inflammatory } \\
\text { bowel diseases }\end{array}$ & $\begin{array}{l}7 \text { patients with inflammatory bowel disease (4 } \\
\text { Crohn's, three ulcerative colitis) received IV infusion of } \\
\text { allogeneic BM-derived or UC-derived MSCs at a dose } \\
\text { of } 1 \times 10^{6} \text { cells } / \mathrm{kg} \text {. }\end{array}$ & $\begin{array}{l}\text { Five patients achieved clinical remission at } 3 \\
\text { months. Endoscopic improvement (assessed by } \\
\text { endoscopic index of severity score) was also } \\
\text { observed in three patients. }\end{array}$ & Cryopreservation was not discussed \\
\hline $\begin{array}{l}\text { 6. de la Portilla et al }(2013)^{87} \\
\text { Phase I/lla multicentre study }\end{array}$ & $\begin{array}{l}24 \text { patients received intralesional injections of } \\
\text { allogeneic adipose derived stem cells at a dose of } \\
20 \times 10^{6} \text { cells. }\end{array}$ & $\begin{array}{l}\text { More than half of patients showed healing of } \\
\text { fistulae at } 6 \text { months. Up to } 30 \% \text { had complete } \\
\text { fistula closure }\end{array}$ & Cryopreserved cells were used \\
\hline $\begin{array}{l}\text { 7. Forbes et al }(2014)^{88} \\
\text { Phase II open-label multicentre } \\
\text { study }\end{array}$ & $\begin{array}{l}16 \text { patients with refractory Crohn's disease received IV } \\
\text { infusion of allogeneic MSCs at a dose of } 2 \times 10^{6} \text { cells/ } \\
\mathrm{kg} \text { weekly for } 4 \text { weeks. }\end{array}$ & $\begin{array}{l}\text { Safe and well-tolerated. Clinical improvement } \\
\text { observed in at least } 12 \text { patients, } 8 \text { of whom } \\
\text { achieved clinical remission } 42 \text { days post-infusion. }\end{array}$ & Cryopreserved cells were used \\
\hline $\begin{array}{l}\text { 8. Molendijk et al }(2015)^{89} \\
\text { Phase I/II double-blind, placebo- } \\
\text { controlled, dose-escalating study }\end{array}$ & $\begin{array}{l}21 \text { patients with refractory fistulating Crohn's disease } \\
\text { received intralesional injection of } 1 \times 10^{7} \text { or } 3 \times 10^{7} \text { or } \\
9 \times 10^{7} \text { allogeneic BM-derived MSC or placebo. }\end{array}$ & $\begin{array}{l}\text { Well tolerated. More significant fistulae healing in } \\
\text { all dosing groups when compared with placebo. } \\
\text { Most observed with } 3 \times 10^{7} \text { dose. }\end{array}$ & $\begin{array}{l}\text { Expanded half-products were } \\
\text { cryopreserved until needed. Two weeks } \\
\text { before treatment, they were thawed } \\
\text { and further expanded to yield sufficient } \\
\text { numbers of cells. }\end{array}$ \\
\hline $\begin{array}{l}\text { 9. Panés et al }(2016)^{90} \\
\text { Phase III randomised, double- } \\
\text { blinded controlled study }\end{array}$ & $\begin{array}{l}212 \text { treatment- refractory Crohn's disease patients } \\
\text { with fistulae. } 107 \text { Patients received } 120 \times 10^{6} \text { allogeneic } \\
\text { adipose derived MSCs as a single intralesional dose, } \\
\text { while } 105 \text { received placebo (saline). }\end{array}$ & $\begin{array}{l}\text { Significantly greater remission rates in the } \\
\text { treatment group compared with the placebo group. } \\
\text { Few adverse events notably proctalgia and anal } \\
\text { abscess. }\end{array}$ & $\begin{array}{l}\text { First phase III study. Effective treatment } \\
\text { option for Crohn's disease patients that } \\
\text { have failed conventional treatment options } \\
\text { Cryopreserved cells were used }\end{array}$ \\
\hline $\begin{array}{l}\text { 10. Dietz et al }(2017)^{91} \\
\text { Phase I trial of autologous stem } \\
\text { cells applied in a bio-absorbable } \\
\text { matrix }\end{array}$ & $\begin{array}{l}12 \text { patients with fistula secondary to Crohn's disease } \\
\text { received autologous adipose-derived MSC embedded } \\
\text { in a Gore Bio-A Fistula Plug through surgical insertion } \\
\text { at a mean dose of } 20 \times 10^{6} \text { per plug }\end{array}$ & $\begin{array}{l}\text { Procedure was safely tolerated and few adverse } \\
\text { events were reported. } 75 \% \text { of patients achieved } \\
\text { complete healing at } 3 \text { months, while } 83.3 \% \\
\text { achieved fistula closure at } 6 \text { months. }\end{array}$ & $\begin{array}{l}\text { Cryopreserved cells were used. Thawed } \\
\text { cells were reincubated with a fistula plug } \\
\text { in a polypropylene coated bioreactor for } \\
3-6 \text { days prior to surgery. This is the first } \\
\text { combination of mesenchymal stromal cells } \\
\text { in a biomaterial for local application in } \\
\text { Crohn's disease. }\end{array}$ \\
\hline
\end{tabular}

BM, bone marrow; MSCs, mesenchymal stromal cells; UC, umbilical cord.

indices, anti-dsDNA titre and circulating Tregs. ${ }^{75-80}$ In the most recent multicentre study, up to $60 \%$ of treated patients achieved either major or partial clinical response as determined by British Isles Lupus Activity Group scores. ${ }^{80}$ However, a relapse rate of $12.5 \%$ at 9 months may warrant repeated infusions of MSCs. An analysis, by the same group, of four patients with diffuse alveolar haemorrhage in SLE using high resolution CT scan showed resolution of lung pathology after treatment with MSCs. ${ }^{81}$

A serious complication of Crohn's disease is perianal fistulae. MSCs have been extensively studied in Crohn's disease for their immunomodulatory properties and for their ability to differentiate into mesodermal tissues with tissue repair capabilities (table 2B). Results in Crohn's disease are encouraging with patients who received MSCs experiencing significant improvement in fistulae while reporting just minor side effects. ${ }^{82-90}$ The unprecedented success of MSCs in a recently concluded phase III multicentre clinical study in Crohn's disease across seven European countries and Israel implies that MSCs could become a treatment of choice for Crohn's fistulae refractory to conventional treatment. In this study, ${ }^{90} 212$ patients with
Crohn's disease-associated fistulae received intralesional injections of either MSCs or placebo. Fifty per cent of the treatment group achieved combined clinical and radiological remission at 24 weeks compared with $34 \%$ of the placebo group, with only minor adverse effects reported. MSC have also been successfully embedded in an absorbable biomaterial and surgically delivered for the treatment of fistulae associated with Crohn's disease. ${ }^{91}$ In this study, 12 patients safely received MSC embedded in a Gore fistula plug with fistula healing rate of $88.3 \%$ at 6 months.

MSCs have also been used in several trials to prevent and treat graft versus host disease (GVHD). In a multicentre phase II study, 55 patients with steroid resistant severe acute GVHD received MSCs at a median dose of $1.4 \times 10^{6}$ cells, obtained either from HLA-identical sibling donors, haploidentical donors or third-party HLA-mismatched donors. Up to 30 patients achieved complete clinical response independent of cell source. ${ }^{92}$ In a recent phase II study, prophylactic MSCs were successfully used to prevent GVHD following HLA-haploidentical stem cell transplantation..$^{93}$ 
A potential advantage of MSC therapy over some other tolerogenic therapies is that their lack of MHC class expression means that they can be derived from either an autologous or allogeneic source with little or no risk of immune rejection. ${ }^{10}$ Thus, cryopreserved allogeneic MSC could become an 'off-the-shelf' therapy rather than a bespoke therapy requiring preparation at the point of delivery. In tables $2 \mathrm{~A}$ and $2 \mathrm{~B}$, the source of MSC is indicated for each trial listed.

\section{Tolerogenic dendritic cells (tolDC)}

In an early murine experiment, allogeneic DC transfer from diabetic non-obese diabetic (NOD) mice to prediabetic NOD mice prevented development of diabetes in the latter. ${ }^{94}$ The hypothesis was that the diabetic NOD mice DC contained pancreatic antigens that conferred immunoregulatory properties, possibly by targeting regulatory $\mathrm{T}$ cells specific to those antigens. Since then, many preclinical studies have demonstrated that ex vivo generated DC, with an anti-inflammatory or tolerogenic phenotype, can effectively suppress or 'switch off' auto-immune disorders such as diabetes, ${ }^{95}{ }^{96}$ arthritis, ${ }^{97}$ MS, ${ }^{99} 99$ autoimmune thyroiditis ${ }^{100}$ and myasthenia gravis. ${ }^{39}$ In most studies, tolDC were pulsed with antigens to confer specificity: bovine serum albumin for bovine serum albumin-induced arthritis, ${ }^{97}$ pancreatic islet lysate for diabetes,${ }^{95}$ encephalitogenic myelin basic protein peptide 68-86 (MBP 68-86) for MS ${ }^{99}$ and thyroglobulin for autoimmune thyroiditis. ${ }^{100}$ Interaction of autoreactive T cells with such partially mature or 'deviated' DC results in their loss of functionality (anergy), apoptosis or acquisition of regulatory function. The majority of the studies aimed at prevention of autoimmunity by administering tolDC in the predisease state (either prophylactically or immediately post-immunisation). ${ }^{39} 9596100$ However, tolDC also arrested established disease, ${ }^{3941}{ }^{97}$ with similar outcomes to prophylactic models. ${ }^{98}$ These studies have been summarised elsewhere. ${ }^{42}$

The first clinical trial of tolDC in a human autoimmune disorder was in type 1 diabetes $^{101}$ (table 3 ). In this study, 10 million autologous DC were safely administered intradermally into patients two times a week for a total of 4 doses, without serious adverse effects. Two forms of DCs were used: immature 'control DC' cultured from monocyte precursors using IL-4 and GM-CSF and immunosuppressive DC (iDC) genetically manipulated ex-vivo to block the expression of costimulatory molecules CD80/CD86. ${ }^{101}$ TolDC were not loaded with autoantigens in this trial. Some therapeutic efficacy was suggested as some patients showed elevated c-peptide levels post-treatment, indicative of increased endogenous insulin production. In a phase I single centre study, tolDC were also safely infused intraperitoneally in patients with refractory Crohn's disease and showed some potential efficacy. ${ }^{102}$ Other studies of TolDC in autoimmunity are in inflammatory arthritis: the AuToDeCRA study where autologous tolDC were loaded with autologous synovial fluid as a source of autoantigen ${ }^{103}$ and the Rheumavax study where autologous tolDC were exposed to citrullinated peptides to confer antigen specificity and administered intradermally to patients with RA. ${ }^{104}$ In the phase I AuToDeCRA study, DC were injected arthroscopically into an inflamed knee joint, as a robust test of their stability and safety in an inflamed environment. There was no evidence that the procedure provoked a flare of symptoms. In a study published only as an abstract, recombinant autoantigen-loaded tolDC were administered subcutaneously to patients with RA at doses of $0.5 \times 10^{7}$ and $1.5 \times 10^{7}$ cells. Dose-dependent efficacy was reported, especially in autoantigen positive patients and autoantibody titres also decreased. ${ }^{105}$ Other trials in Crohn's disease, RA and MS are ongoing and results are yet to be published. ${ }^{27}$

A potential advantage of (autoantigen-loaded) tolDC compared with MSC is their capacity to specifically target autoreactive T cells, without non-specific immune suppression. ${ }^{103} 104$ Other similar antigen-specific cells are actively being investigated, especially in transplantation. These include regulatory macrophages (Mregs), ${ }^{106-108}$ myeloid derived suppressor cells ${ }^{109}$ and MSC-conditioned monocytes. ${ }^{110}$ While other applications

Table 3 Clinical trials of ToIDC in autoimmune disorders

\begin{tabular}{|c|c|c|c|}
\hline Diseases and clinical trials & $\begin{array}{l}\text { Number of patients, source of cells, dose and route } \\
\text { of administration }\end{array}$ & Outcomes & Comments \\
\hline \multicolumn{4}{|l|}{ Diabetes mellitus } \\
\hline $\begin{array}{l}\text { 1. Giannoukakis et al }(2011)^{101} \\
\text { A randomised double-blind } \\
\text { phase I study }\end{array}$ & $\begin{array}{l}10 \text { patients with type } 1 \text { diabetes received } 10 \times 10^{6} \\
\text { autologous peripheral blood-derived dendritic cells } \\
\text { intradermally every } 2 \text { weeks for } 4 \text { administrations ( } 7 \\
\text { received ex vivo manipulated DC lacking CD80/CD86 } \\
\text { while } 3 \text { controls received non-manipulated immature } \\
\text { DCs). }\end{array}$ & $\begin{array}{l}\text { Safely tolerated. Significant increase in the } \\
\text { proportion of } B 220^{+} \text {CD } 11 c^{-} \text {B cells, mainly in } \\
\text { patients that received manipulated dendritic } \\
\text { cells. Detectable C-peptide in patients that had } \\
\text { undetectable pretreatment C-peptide. }\end{array}$ & $\begin{array}{l}\text { First use of tolerogenic dendritic cells in } \\
\text { human autoimmunity. }\end{array}$ \\
\hline
\end{tabular}

\section{Crohn's disease}

2. Jauregui-Amezaga et al $(2015)^{102}$

Phase I dose escalation study DCs).

Rheumatoid and inflammatory arthritis

3. Benham et al (2015) 34 patients with RA carrying HLA-DRB1 'shared epitope' Phase I randomised controlled allele. 18 received autologous monocyte-derived tolDC study (depending on yield) while 16 were controls

$\begin{array}{lll}\begin{array}{l}\text { 4. Bell et al (2016) } \\ \text { Phase I unblinded randomised }\end{array} & \begin{array}{l}\text { Monocyte-derived autologous tolDC. Three cohorts of } \\ \text { patients with rheumatoid or other inflammatory arthritis }\end{array} & \begin{array}{l}\text { Safe and acceptable procedure, feasible to } \\ \text { manufacture tolDC from peripheral blood of }\end{array} \\ \text { controlled dose escalation study } & \begin{array}{l}\text { received } 1 \times 10^{6}, 3 \times 10^{6} \text {, or } 10 \times 10^{6} \text { cells into an inflamed } \\ \text { knee. DC exposed to synovial fluid during culture as a } \\ \text { source of auto-antigen. A fourth (control) cohort received with arthritis. Arthroscopically assessed } \\ \text { arthroscopic washout alone. }\end{array} & \begin{array}{l}\text { synovial vascularity and synovitis improved in } \\ \text { some patients who received TolDC. }\end{array} \\ & \end{array}$

Well tolerated. Low grade adverse events including transient leucopoenia, anaemia and transaminitis. Treatment was associated with reduction in effector $T$ cells and an increased regulatory:effector $\mathrm{T}$ cell ratio. tolDC injection or follow-up. Some anecdotal efficacy was observed and one patient achieved TolDC were not loaded with specific antigens. Three patients withdrew due to worsening symptoms. No consistent immunomodulatory trend in peripheral blood between treatment and control groups. No evidence for DC-induced joint flare (indicating DC stability).
First use of dendritic cells for treatment of RA. TolDC were exposed to citrullinated peptides to confer antigen specificity 
remain preclinical, regulatory macrophages have been studied in humans in the context of renal transplantation. In a recent case report, ${ }^{108}$ two patients received donor-derived Mregs at doses of $7.1 \times 10^{6}$ and $8 \times 10^{6}$ cells $/ \mathrm{kg}$ intravenously prior to receiving living donor renal transplants. Both patients were eventually weaned from steroids over 10 weeks leaving maintenance low dose tacrolimus. Transfused Mregs were shown to secrete IL-10 and suppress T cell proliferation by cell-cell contact and IFN- $\gamma$ induced IDO activity. ${ }^{108}$ Both patients showed increased numbers of circulating Tregs post-transplant and a peripheral blood gene expression profile indicative of tolerance according to the Indices of Tolerance (IOT) research network. ${ }^{111}$

\section{Regulatory T cells}

'Natural' CD $4{ }^{+} \mathrm{CD} 25^{+} \mathrm{FoxP}^{+}$regulatory T cells (Tregs) play a central role in immune tolerance in health. While the evidence is not always definitive, Treg defects or deficiencies have been implicated in several autoimmune diseases. ${ }^{47} 112$ As with MSCs and DCs, considerable effort has therefore been dedicated to developing methodologies to isolate and expand these cells, as a potential tolerogenic therapy for autoimmune disease. Isolation uses the cell surface markers CD4, CD25 and usually CD127 $7^{\text {low }}$. Subsequent expansion generally uses anti-CD3, anti-CD28 and IL-2 (figure 2). The expanded cells can, in theory, be rendered disease-specific by expansion in the presence of relevant autoantigens or genetic manipulation of TCR expression. ${ }^{113}$ Expanded Tregs have been used preclinically to treat murine models of autoimmunity, especially type 1 diabetes $^{114-118}$ and, in some studies, Tregs were expanded with DCs to confer antigen specificity. In humans, early trials took place in patients with GVHD following bone marrow transplantation. For example, transfusion of HLA partially matched allogeneic umbilical cord blood derived Tregs at a dose of $0.1-30 \times 10^{5} \mathrm{Treg} / \mathrm{kg}$, following double umbilical cord blood transplantation, was associated with a reduced incidence of acute GVHD when compared with identically treated controls without Treg. ${ }^{119}$ Tregs have also been used in a phase I study to prevent GVHD by infusing donor-specific ex-vivo expanded Tregs prior to haploidentical haematopoietic stem cell transplantation without post-transplantation GVHD prophylaxis. ${ }^{120}$

The first description of expanded Treg administration in human autoimmunity was in children with type 1 diabetes. ${ }^{121}$ Ten children received intravenous injections of autologous Tregs in two dosing cohorts $\left(10 \times 10^{6}\right.$ and $20 \times 10^{6}$ cells $\left./ \mathrm{kg}\right)$ and followed for 6 months (table 4). A matched control group was used to compare clinical improvement after infusion. The treatment group, on average, had lower insulin requirements at 6 months compared with their matched controls. In an extension of this study, a higher dose of up to $30 \times 10^{6}$ cells $/ \mathrm{kg}$ was well tolerated and associated with some clinical improvement after 12 months (reduction in insulin requirement and higher C-peptide levels). ${ }^{122}$ In a recent study in adults with newly diagnosed type 1 diabetes, ${ }^{50}$ a dose escalation protocol was used to assess the maximum tolerated dose of Tregs. Patients received intravenous infusions of Tregs up to a target dose of $2.3 \times 10^{9}$ cells, experiencing no serious adverse effects. In vitro analysis showed that expansion of the Tregs increased the overall number of cells and their functional activity/potency. In this study, the DNA of expanded Tregs was labelled with deuterium, allowing in vivo tracking. Up to $25 \%$ of transfused Tregs survived in the peripheral blood after 1 year. Furthermore, deuterium did not appear in other lymphocyte populations suggesting expanded Tregs were stable after administration. Autologous $\operatorname{Tr} 1$ cells were also well tolerated when administered intravenously in 20 patients with Crohn's disease with associated improvement in disease activity. $^{123}$

Concerns have been raised about the potential plasticity of Tregs in relation to their reliability as a cellular therapy. Natural Tregs form a relatively small proportion of peripheral blood CD4 + $\mathrm{T}$ cells and express no unique surface marker to facilitate their isolation. Nonetheless, enrichment of CD127/low cells generally suffices to minimise contamination with activated $\mathrm{T}$ cells. However, the propensity for expanded Tregs to express IL-17 was noted some years ago, with evidence suggesting that $\mathrm{CD} 4{ }^{+} \mathrm{CD} 25^{+} \mathrm{FoxP}^{+}$Tregs can undergo transformation to pathogenic Th17 cells after repeated expansion. ${ }^{124-126}$ These studies demonstrated that epigenetic instability of the FoxP3 and retinoic acid receptor-related orphan receptor (RORC) loci accounted for the potential for Th17 (de-)differentiation. Further investigation demonstrated that both loci were stable in 'naïve' (CD45RA $\left.{ }^{+}\right)$Tregs, when compared with memory $\left(\mathrm{CD} 45 \mathrm{RO}^{+}\right.$) Tregs. ${ }^{126} 127$ Therefore, use of CD45RA as an additional marker for Treg isolation should minimise expansion-induced epigenetic instability and produce a more homogenous tolerogenic Treg population, with low risk of Th17 transformation. In mice, evidence exists for cells that coexpress FoxP3 and ROR $\gamma \mathrm{T}$, the murine equivalent of the Th17-lineage defining marker RORC. ${ }^{128}$ Despite a capacity to differentiate into either classical Tregs or Th17 cells, these cells demonstrated a regulatory function in murine diabetes.

The development of $\operatorname{Tr} 1$ cells as a therapy is at an earlier stage than regulatory $\mathrm{T}$ cell therapy. They can be expanded ex vivo from PBMC or CD4+ T cells. One method, using an IL-10 secreting DC (DC-10), can generate allospecific $\operatorname{Tr} 1$ cells for potential use in haematological or solid organ transplantation. An alternative technique generated ova-specific $\operatorname{Tr} 1$ cells for a phase $1 \mathrm{~b} / 2 \mathrm{a}$ clinical trial in Crohn's disease. ${ }^{123}$

\section{In vivo expansion of regulatory $\mathrm{T}$ cells}

IL-2 is a key cytokine for $\mathrm{T}$ cell activation and proliferation. Furthermore, because natural Tregs express high levels of CD25, the IL-2 receptor alpha chain, they are highly sensitive to stimulation by IL-2. In patients with cancer treated with peptide vaccine ${ }^{129}$ and DC-based vaccine immunotherapy, ${ }^{130} 131$ administration of IL-2 (with a rationale to expand effector T cells) actually led to in-vivo expansion of Tregs. This led to the theory that IL-2, particularly at low doses, will preferentially expand Tregs, informing preclinical experiments and clinical trials in autoimmunity. In a cohort of patients with chronic refractory GVHD, low dose IL-2 administration $\left(0.3-1 \times 10^{6} \mathrm{IU} / \mathrm{m}^{2}\right)$ increased Treg:Teff ratio, with improvement in clinical symptoms and enabling tapering of steroid dose by a mean of $60 \% .{ }^{132}$ Similarly, low dose IL-2 $\left(1-2 \times 10^{5} \mathrm{IU} / \mathrm{m}^{2}\right)$ post-allogeneic SCT in children prevented acute GVHD when compared with those who did not receive low dose IL-2. ${ }^{133}$

Treatment of patients with Hepatitis $\mathrm{C}$ virus-induced, cryoglobulin-associated vasculitis with IL-2 at a dose of $1.5 \times 10^{6}$ IU once a day for 5 days followed by $3 \times 10^{6}$ IU for 5 days on weeks 3, 6 and 9 was associated with clinical improvement in $80 \%$ of patients as well as a reduction in cryoglobulinaemia and normalisation of complement levels. ${ }^{134}$ In a phase I trial in type 1 diabetes, administration of $2-4 \mathrm{mg} /$ day of rapamycin and $4.5 \times 10^{6}$ IU IL-2 thrice per week for 1 month led to a transient increase in Tregs but a paradoxical worsening of $\beta$-cell function, associated with an increase in circulating NK-cells and eosinophils. ${ }^{135}$ In SLE, a Treg defect associates with disease activity and 
Table 4 Clinical trials with expanded regulatory T cells (Tregs) in autoimmunity

\begin{tabular}{|c|c|c|c|}
\hline Diseases and clinical trials & $\begin{array}{l}\text { Number of patients, source of cells, dose and route of } \\
\text { administration }\end{array}$ & Outcomes & Comments \\
\hline \multicolumn{4}{|l|}{ Ex-vivo expanded Tregs } \\
\hline \multicolumn{4}{|l|}{ Diabetes } \\
\hline $\begin{array}{l}\text { 1. Marek-Trzonkowska et al } \\
(2012)^{121} \\
\text { Phase I non-randomised } \\
\text { study }\end{array}$ & $\begin{array}{l}10 \text { children with type } 1 \text { diabetes received autologous Tregs } \\
\text { intravenously in two dosing cohorts }\left(10 \times 10^{6} \text { and } 20 \times 10^{6} \text { cells/ }\right. \\
\mathrm{kg} \text { body weight). A matched control group of } 10 \text { children did } \\
\text { not receive a placebo. In the extension study, }{ }_{1}^{122} \text { two extra } \\
\text { patients were recruited for treatment, and } 6 \text { out of the total } 12 \\
\text { patients received an additional infusion at } 6-9 \text { months (either } \\
\left.10 \times 10^{6} \text { or } 20 \times 10^{6} \text { cells } / \mathrm{kg}\right) \text { making up a total dose of } 30 \times 10^{6} \\
\text { cells } / \mathrm{kg} \text {. Here, patients were followed up for } 1 \text { year. }\end{array}$ & $\begin{array}{l}\text { No serious adverse events. Generally, treated children } \\
\text { had lower insulin requirements at } 6 \text { months compared } \\
\text { with matched controls, and recorded significantly } \\
\text { higher c-peptide levels. A higher dose of } 30 \times 10^{6} \text { cells/ } \\
\text { kg was also safely tolerated and was associated with } \\
\text { better clinical outcomes (more patients in this group } \\
\text { achieved remission, at } 1 \text { year with highest fasting and } \\
\text { stimulated c-peptide levels and lowest HbA1C levels. }\end{array}$ & $\begin{array}{l}\text { First in-human study of Tregs for } \\
\text { autoimmunity }\end{array}$ \\
\hline $\begin{array}{l}\text { 2. Bluestone et al }(2015)^{50} \\
\text { Phase I dose-escalation } \\
\text { study }\end{array}$ & $\begin{array}{l}14 \text { adults with type } 1 \text { diabetes received intravenous autologous } \\
\text { polyclonal Tregs in four dosing cohorts ( } 0.056 \text { to } 23.5 \times 10^{8} \\
\text { cells). }\end{array}$ & $\begin{array}{l}\text { Safe. Transferred Tregs were long-lived and stable, with } \\
\text { up to } 25 \% \text { surviving up to } 1 \text { year. Small sample size } \\
\text { and heterogeneity of diabetes did not allow for efficacy } \\
\text { assessment }\end{array}$ & $\begin{array}{l}\text { Expanded Tregs had up to } 4-8 \text {-fold } \\
\text { higher suppressive activity than } \\
\text { non-expanded Tregs from the same } \\
\text { individual }\end{array}$ \\
\hline \multicolumn{4}{|l|}{ Crohn's disease } \\
\hline $\begin{array}{l}\text { 3. Desreumaux et al } \\
(2012)^{123} \\
\text { Phase I/Ila multicentre study }\end{array}$ & $\begin{array}{l}20 \text { patients with refractory Crohn's disease received } \\
\text { intravenously ovalbumin-specific Tr1 cells at } 4 \text { dose cohorts } \\
\left(10^{6}, 10^{7}, 10^{8}, 10^{9} \text { cells }\right)\end{array}$ & $\begin{array}{l}\text { Safely tolerated with few adverse events. Clinical } \\
\text { improvement with a reduction in Crohn's disease } \\
\text { activity index and inflammatory bowel disease } \\
\text { questionnaires }\end{array}$ & $\begin{array}{l}\text { First in human study of use of Tr1 } \\
\text { cells for treatment of autoimmunity. } \\
\text { Authors argue that ovalbumin is } \\
\text { widely distributed in the GI tract } \\
\text { and will activate Tr1 cells. }\end{array}$ \\
\hline
\end{tabular}

\begin{tabular}{|c|c|c|c|}
\hline \multicolumn{4}{|l|}{ In-vivo expanded Tregs } \\
\hline \multicolumn{4}{|l|}{ HCV-induced vasculitis } \\
\hline $\begin{array}{l}\text { 4. Saadoun et al (2011) } \\
\text { Phase I/Ila study in HCV- } \\
\text { induced vasculitis }\end{array}$ & $\begin{array}{l}10 \text { patients with HCV-induced vasculitis refractory to HCV } \\
\text { therapy received } 1.5 \times 10^{6} \mathrm{IU} \text { subcutaneous (SC) IL-2 daily for } 5 \\
\text { days, followed by three } 5 \text { day courses of } 3 \times 10^{6} \text { IU/day at weeks } \\
3,6 \text { and } 9 \text {. }\end{array}$ & $\begin{array}{l}\text { Safe with no major adverse events. There was a } \\
\text { reduction in cryoglobulinaemia in } 90 \% \text { of patients and } \\
\text { improvement in vasculitis in } 80 \% \text {. Fox } 3^{+} \text {Tregs also } \\
\text { increased in peripheral blood. }\end{array}$ & $\begin{array}{l}\text { Treatment did not induce effector } \\
\text { T cell activation, vasculitis flare, or } \\
\text { increased HCV viremia }\end{array}$ \\
\hline
\end{tabular}

Diabetes

$\begin{array}{ll}\begin{array}{l}\text { 5. Long et al }(2012)^{135} \\ \text { Phase } 1 \text { study in type } 1\end{array} & \begin{array}{l}9 \text { patients with type } 1 \text { diabetes received 2-4 mg/day rapamycin } \\ \text { for } 3 \text { months and } 4.5 \times 10^{6} \text { IU IL-2 SC. thrice weekly for } 1 \text { month, }\end{array} \\ \begin{array}{ll}\text { diabetes Hartemann et al }(2013)^{158} & 24 \text { patients with type } 1 \text { diabetes received either a placebo or } \\ \text { Phase I/II randomised, } & \text { one of three doses of IL-2. }\left(0.33 \times 10^{6} \mathrm{IU} / \text { day, } 1 \times 10^{6} \mathrm{IU} / \text { day or }\right. \\ \text { double-blind placebo- } & 3 \times 10^{6} \text { IU/day) SC for } 5 \text { days } \\ \text { controlled study in diabetes }\end{array}\end{array}$

7. Todd et al (2016) $)^{140} \quad 40$ adults with type 1 diabetes received one injection of IL-2 Phase I/II non-randomised, SC in different dosing cohorts $\left(0.04 \times 10^{6}\right.$ to $\left.1.5 \times 10^{6} \mathrm{IU} / \mathrm{m}^{2}\right)$ open label, adaptive dose- and followed up for 7 days. The end point was the maximum finding trial percentage increase in Tregs $\left(C D 3^{+} C D 4^{+} C D 25^{\text {high }} C D 127^{\text {low }}\right)$ from baseline frequency.

8. Seelig et al (2017) ${ }^{142} \quad 36$ patients with type 1 diabetes received IL-2 at different dose- Well tolerated apart from injection site reactions. The Phase I/II response-adaptive frequency combinations. Preliminary analysis of all accumulated optimum regimen to maintain a steady state increase trial of repeat doses of IL-2 data after completion of each cohort informed dose-frequencies in Treg of $30 \%$ and CD25 expression of $25 \%$ without in diabetes of the following cohort. An initial learning phase involved Teff expansion was $0.26 \times 10 \mathrm{IU} / \mathrm{m}^{2}$ every 3 days.

\section{ALOPECIA AREATA}

9. Castela et al (2014) 5 patients received $1.5 \times 10^{6} \mathrm{IU} /$ day IL-2 SC for 5 days followed Safe with improvement in severity of alopecia

Case series of low dose IL-2 by 3 courses of $3 \times 10^{6}$ IU/day at weeks 3,6 , and 9 .

in alopecia areata

tool (SALT) score (evaluated by two independent investigators). Significant increase in the number of Tregs was also seen in $80 \%$ of patients.
10. Humrich et al (2015) $)^{137} 1$ patient received four treatment cycles of $1.5 \times 10^{6}$ or $3 \times 10^{6} \mathrm{IU} \quad$ Clinical improvement was observed with reduction in A case report of low-dose IL-2 SC for five consecutive days with a washout period of 9-16 anti-ds-DNA titre and SLEDAl score,

IL-2 in a patient with refractory SLE

\section{1. von Spee-Mayer et al $\quad 5$ patients with refractory SLE were treated daily with $1.5 \times 10^{6}$} $(2016)^{136}$

Phase I study in refractory IU IL-2 SC for five consecutive days

12. He et al (2016) $)^{138}$ Phase I study in active SLE increased number of FoxP3 ${ }^{+} \mathrm{CD} 25^{\text {high }} \mathrm{CD} 27^{\text {low }}$ Tregs during the treatment course.
Safe with increased CD25 expression in Tregs and
Preprint data at the time of this review
First evidence of possible therapeutic effect of low dose IL-2 in SLE.

\footnotetext{
IL, interleukin; SLE, systemic lupus erythematosus; SLEDAI, Systemic Lupus Erythematosus Disease Activity Index; UC, umbilical cord.
} 
appears secondary to defective endogenous IL-2 production. ${ }^{136}$ Exogenous low dose IL-2 appears to both reverse the biological defect and provide a potential therapeutic strategy. ${ }^{136-138}$

A common finding in trials of low dose IL-2 to treat autoimmunity is that effects are transient, declining once treatment is discontinued. Effects may not be limited to natural Tregs but also extend to FoxP $3{ }^{+} \mathrm{CD}^{+}{ }^{+} \mathrm{T}$ cells, at least in type 1 diabetes. ${ }^{139}$ However, an optimum dosing regime is yet to be defined. Results from a recent adaptive dose-finding study in 40 patients with type 1 diabetes suggest that the optimal dose of a single injection of IL-2 that will induce $10 \%$ and $20 \%$ increases in Tregs over 7 days were approximately $0.10 \times 10^{6} \mathrm{IU} / \mathrm{m}^{2}$ and $0.5 \times 10^{6} \mathrm{IU} /$ $\mathrm{m}^{2}$, respectively. ${ }^{140}$ This study also showed that the mean plasma concentrations of IL-2 at 90 min postinjection, even at the lowest doses, were higher than the hypothetical Treg-specific therapeutic window determined in vitro $(0.015-0.24 \mathrm{IU} / \mathrm{mL})$. This was associated with a dose-dependent transient desensitisation of Tregs (downmodulation of the beta subunit of IL-2 receptor (CD122)) and a decrease in the number of circulating Tregs and other lymphocytes, which improved 2 days after injection. These findings may explain the lack of response seen in some patients who have received daily injections of low-dose IL-2. A follow-on study by the same group investigated the optimum frequency of administration of IL-2 in type 1 diabetes. ${ }^{141}$ Results show that the optimum regimen to maintain a steady state increase in Treg of $30 \%$ and CD25 expression of $25 \%$ without Teff expansion was $0.26 \times 10 \mathrm{IU} / \mathrm{m}^{2}$ every 3 days. ${ }^{142}$

It is unclear at this juncture whether in vivo expansion of Tregs might provide a superior therapeutic option in autoimmunity than ex vivo expansion and readministration. Conceivably the two modalities could be combined. Other attempts have been made to expand Tregs in vivo. One method is the administration of autoantigen in Freund's incomplete adjuvant. In a phase I trial, a single dose of insulin- $\beta$-chain in IFA was administered intramuscularly to patients with type 1 diabetes. ${ }^{143}$ Treatment was well tolerated and appeared to stimulate robust antigen-specific regulatory $\mathrm{T}$ cell populations in the treatment arm up to 24 months, although there was no statistically significant difference in mixed meal stimulated c-peptide responses compared with the control group. Other methods are the probiotic use of whole helminths or their unfractionated products and administration of purified excretory/secretory helminths' products. In preclinical studies using animal models of RA, MS, Crohn's disease and type 1 diabetes, they induce Tregs (and other regulatory cells) in vivo and prevent autoimmunity. ${ }^{144-146}$ However, clinical trials are yet to show consistent encouraging results in humans. ${ }^{145}$

\section{WHERE ARE WE NOW?}

Results to date from human clinical trials have shown that cellular therapies are, at minimum, safe and feasible, and therefore worth exploring further in our pursuit of therapeutic tolerance induction. The regenerative properties of MSCs could additionally provide an element of tissue replenishment, repairing some of the damage that inevitably accompanies autoimmunity. However, most of the studies outlined in this review are at the very earliest phases of clinical development. Phase II and, ultimately, phase III studies will be needed to confirm their efficacy. Furthermore, as with any tolerogenic therapy in autoimmunity, clear objectives are required for efficacy trials. In transplantation, 'operational tolerance' is present when immunosuppression can be removed without allograft rejection. The situation is less clear in autoimmunity. Re-establishment of self-tolerance should equate with life-time drug-free remission, which has been demonstrated in some animal models when tolerogenic cells are administered both prophylactically and therapeutically. ${ }^{42} 95$ However, tolerance takes time to develop and tolerogenic therapies may not reduce symptoms in the short-term, necessitating the temporary continuation of more conventional therapies. Furthermore, immunosuppressive drugs and glucocorticoids could potentially interfere with tolerance induction as previously suggested for calcineurin inhibitors. ${ }^{147}$ Careful clinical trial designs will therefore be fundamental in order to identify, robustly, tolerance induction. In the short term, this is likely to require immune monitoring, for example, using autoantibody arrays and MHC-peptide tetramers, in order to track and interrogate the quality and quantity of the autoantigen-specific response. ${ }^{148} 149$ To date, cellular therapy trials have only occasionally incorporated experimental medicine end-points, for example, to measure longevity of cells, their distribution in vivo or to determine appropriate dosage. ${ }^{123} 140$ It is important that future trials adopt a similar philosophy, both to advance therapeutic development and also for ethical reasons.

Other factors to consider during the development of tolerogenic cellular therapies include the route of delivery. For more standard therapeutics, the main decision is usually oral vs parenteral delivery. For cellular therapies, the route has to be parenteral but the decision is potentially more sophisticated. For example, where might TolDC regulate an aberrant autoimmune response? In the target tissue, the draining lymph nodes, the central lymphoid organs? Route of delivery is likely to influence the therapy's ultimate destination, and treatment development needs to encompass work that demonstrates the cells express appropriate homing receptors. And then, there are the more standard developmental questions such as dosage and frequency of administration - a true tolerogenic therapy should only require a single 'course' of treatment but, in a patient with a propensity to autoimmunity, regular re-treatments may be required to keep autoreactivity at bay. Choice of autoantigen is also critical for certain cellular therapies. And last, cost-effectiveness has to be demonstrated for any novel treatment. However, the health economics would be very different for a tolerogenic therapy if it could truly avoid the need for chronic immunosuppressive therapy and its complications, not to mention the ravages of autoimmunity-associated tissue damage and comorbidities, such as cardiovascular disease.

The costs of isolating and expanding cells for therapy are significant but collaborations across academic research centres and commercial partners will solve some logistical challenges of clinical grade manufacture. Such challenges include cell source, cell isolation and expansion techniques, culture media and reagents, potency markers and genetic manipulation techniques where required (figure 2). These need to be standardised to ensure reproducibility because different cell manufacturing techniques will lead to subtle or even unidentified phenotypic differences in the final product. For example, it is unclear whether different types of tolDC, manufactured using distinct techniques, will have significantly different clinical effects. ${ }^{150}$ Measurement of potency is therefore a critical step prior to the release and administration of any cellular therapy product. ${ }^{151}$

At one point, the costs of cell manufacturing were envisaged to be a potential barrier to the development of immunomodulatory cell therapies. However, with the success of cellular therapeutics such as chimeric antigen receptor $\mathrm{T}$ cells for cancer, significant investment has been made in relevant technologies. For example, closed bioreactors can enable manufacture of large quantities of GMP-grade cells within a shorter period of time than labour-intensive, open culturing in flasks and bags. ${ }^{152}$ Such technologies 
are inherently adaptable, and therefore transferrable to different types of cellular therapy, ${ }^{153}$ helping to achieve cost-effectiveness and reducing batch-to-batch variability.

Eventually, and assuming positive results, comparative effectiveness trials across cell types (MSCs, TolDC and Tregs) may be required to determine which products are best suited for different forms and stages of autoimmunity. For example, MSCs, because of their regenerative capacity, may be favoured in conditions such as Crohn's disease and MS where tissue regeneration would be advantageous. On the contrary, Tregs may be preferred in diseases with documented evidence of Treg dysfunction such as type 1 diabetes and SLE, because ex-vivo expansion of Tregs can reverse Treg dysfunction. ${ }^{154}$ The effects of different cell types is being investigated in transplantation in The ONE Study. ${ }^{155} \mathrm{In}$ this collaborative study, different immunosuppressive cell populations (tolerogenic macrophages, myeloid derived suppressor cells, tolDC, monocytes conditioned by MSCs, IL-10 induced DCs and rapamycin-conditioned DCs) are manufactured from the same leukapheresis product, removing one element of variability when comparing these very different therapies. Cells are then studied in different disease contexts to determine the best approach to treatment. It may also prove possible to combine different cells to produce synergistic effects.

As tolerance can break down many years before the onset of clinical disease, it is also important to consider the optimal timing of cellular therapies. Detection of preclinical autoimmunity may provide a window of opportunity to treat and cure these diseases with safe interventions before symptom onset and before tissue damage has accrued. Epitope spreading, with broadening of the autoimmune repertoire alongside the non-specific effects of tissue damage, might render therapeutic tolerance induction more difficult in established disease, despite phenomena such as infectious tolerance and linked suppression. ${ }^{156}$ Appropriate immune monitoring will be even more important in disease, as a means to establish benefit in the absence of symptoms or signs. In-depth studies of allograft recipients who have achieved operational tolerance have identified biomarkers that appear specific for the tolerant state. These may be useful for monitoring attempts at tolerance induction prospectively. ${ }^{157}$

\section{CONCLUSION}

It is an exciting time for tolerogenic cellular therapies. Rapid advances can be expected in the short to medium term catalysed by progress in manufacturing technologies, advances in the development of immune monitoring techniques and the identification of tolerance biomarkers, alongside an acceptance that earlier treatment may be ethically justified if the therapeutic target is tolerance induction. Whether any, or all, of the cells discussed in this review will ultimately demonstrate robust tolerogenic effects must await formal clinical trials of efficacy; and we should be as certain as we can be that the timing, route and dosing of therapy is optimal before conducting the 'definitive' studies. These are not easy challenges but they are tractable and, currently, there is a large amount of intellectual energy directed at solving them.

Contributors The outline of the article was developed by JDI and CHM. The first draft of the article was prepared by CHM. Subsequent drafts were prepared by CHM following suggestions and amendments by JDI. Figures and tables were prepared by CHM and approved by JDI. Both authors approved the final submitted article and its revision in response to Reviewers' comments.

Funding This work was supported by the National Institute for Health Research Newcastle Biomedical Research Centre based at Newcastle upon Tyne Hospitals NHS Foundation Trust and Newcastle University. The authors' work is supported by the Arthritis Research UK (ARUK)-Newcastle Biomedicine Experimental Arthritis Treatment Centre, the ARUK Centre of Excellence in RA Pathogenesis and by the
European Commission Innovative Medicines Initiative Rheuma-Tolerance for Cure (RT-CURE).

Disclaimer The views expressed are those of the authors and not necessarily those of the NHS, the NIHR or the Department of Health.

Competing interests None declared.

Patient consent Not required.

Provenance and peer review Not commissioned; externally peer reviewed.

Open access This is an open access article distributed in accordance with the Creative Commons Attribution 4.0 Unported (CC BY 4.0) license, which permits others to copy, redistribute, remix, transform and build upon this work for any purpose, provided the original work is properly cited, a link to the licence is given, and indication of whether changes were made. See: http://creativecommons.org/ licenses/by/4.0/

\section{REFERENCES}

1 Baker KF, Isaacs JD. Novel therapies for immune-mediated inflammatory diseases: what can we learn from their use in rheumatoid arthritis, spondyloarthritis, systemic lupus erythematosus, psoriasis, Crohn's disease and ulcerative colitis? Ann Rheum Dis 2018;77:175-87.

2 Schett G, Emery P, Tanaka Y, et al. Tapering biologic and conventional DMARD therapy in rheumatoid arthritis: current evidence and future directions. Ann Rheum Dis 2016;75:1428-37.

3 Liu B, Shu S, Kenny TP, et al. Stem cell therapy in autoimmune rheumatic diseases: a comprehensive review. Clin Rev Allergy Immunol 2014;47:244-57.

4 Zeher M, Papp G, Nakken B, et al. Hematopoietic stem cell transplantation in autoimmune disorders: from immune-regulatory processes to clinical implications. Autoimmun Rev 2017;16:817-25.

5 Baker KF, Isaacs JD. Prospects for therapeutic tolerance in humans. Curr Opin Rheumatol 2014;26:219-27.

6 Maartens JH, De-Juan-Pardo E, Wunner FM, et al. Challenges and opportunities in the manufacture and expansion of cells for therapy. Expert Opin Biol Ther 2017; 17:1221-33.

7 Keating A, Horwitz EM, Andreef M. Mesenchymal stromal cells. Curr Opin Hematol 2006:13:419-25

8 Wang L, Zhao Y, Shi S. Interplay between mesenchymal stem cells and lymphocytes: implications for immunotherapy and tissue regeneration. J Dent Res 2012;91:1003-10.

9 Burr SP, Dazzi F, Garden OA. Mesenchymal stromal cells and regulatory T cells: the Yin and Yang of peripheral tolerance? Immunol Cell Biol 2013;91:12-18.

10 Pistoia V, Raffaghello L. Mesenchymal stromal cells and autoimmunity. Int Immunol 2017:29:49-58

11 Dominici M, Le Blanc K, Mueller I, et al. Minimal criteria for defining multipotent mesenchymal stromal cells. The International Society for Cellular Therapy position statement. Cytotherapy 2006;8:315-7.

12 Waterman RS, Tomchuck SL, Henkle SL, et al. A new mesenchymal stem cell (MSC) paradigm: polarization into a pro-inflammatory MSC1 or an Immunosuppressive MSC2 phenotype. PLoS One 2010;5:e10088.

13 Romieu-Mourez R, François M, Boivin MN, et al. Cytokine modulation of TLR expression and activation in mesenchymal stromal cells leads to a proinflammatory phenotype. J Immunol 2009;182:7963-73.

14 Maccario R, Podestà M, Moretta A, et al. Interaction of human mesenchymal stem cells with cells involved in alloantigen-specific immune response favors the differentiation of CD4+ T-cell subsets expressing a regulatory/suppressive phenotype. Haematologica 2005;90:516-25.

15 Corcione A, Benvenuto F, Ferretti E, et al. Human mesenchymal stem cells modulate B-cell functions. Blood 2006;107:367-72.

16 da Silva Meirelles L, Chagastelles PC, Nardi NB. Mesenchymal stem cells reside in virtually all post-natal organs and tissues. J Cell Sci 2006;119(Pt 11):2204-13.

17 Steinman RM, Nussenzweig MC. Avoiding horror autotoxicus: the importance of dendritic cells in peripheral T cell tolerance. Proc Natl Acad Sci U S A 2002;99:351-8.

18 Hilkens CM, Isaacs JD. Tolerogenic dendritic cell therapy for rheumatoid arthritis: where are we now? Clin Exp Immunol 2013;172:148-57.

19 Ganguly D, Haak S, Sisirak V, et al. The role of dendritic cells in autoimmunity. Nat Rev Immunol 2013;13:566-77.

20 Kaliński P, Hilkens CM, Wierenga EA, et al. T-cell priming by type-1 and type2 polarized dendritic cells: the concept of a third signal. Immunol Today 1999;20:561-7

21 Diebold SS. Determination of T-cell fate by dendritic cells. Immunol Cell Biol 2008;86:389-97.

22 Goubier A, Dubois B, Gheit $\mathrm{H}$, et al. Plasmacytoid dendritic cells mediate oral tolerance. Immunity 2008;29:464-75.

23 Mellor AL, Baban B, Chandler P, et al. Cutting edge: induced indoleamine 2,3 dioxygenase expression in dendritic cell subsets suppresses T cell clonal expansion. J Immunol 2003;171:1652-5. 
24 Coombes JL, Siddiqui KR, Arancibia-Cárcamo CV, et al. A functionally specialized population of mucosal CD103+ DCs induces Foxp3+ regulatory T cells via a TGFbeta and retinoic acid-dependent mechanism. J Exp Med 2007;204:1757-64.

25 Sun CM, Hall JA, Blank RB, et al. Small intestine lamina propria dendritic cells promote de novo generation of Foxp3 T reg cells via retinoic acid. J Exp Med 2007;204:1775-85.

26 Stoop JN, Robinson JH, Hilkens CM. Developing tolerogenic dendritic cell therapy for rheumatoid arthritis: what can we learn from mouse models? Ann Rheum Dis 2011;70:1526-33.

27 Obregon C, Kumar R, Pascual MA, et al. Update on dendritic cell-induced immunological and clinical tolerance. Front Immunol 2017;8:1514.

28 Liang X, Lu L, Chen Z, et al. Administration of dendritic cells transduced with antisense oligodeoxyribonucleotides targeting CD80 or CD86 prolongs allograft survival. Transplantation 2003;76:721-9.

29 Chen T, Xu H, Wang HQ, et al. Prolongation of rat intestinal allograft survival by administration of triptolide-modified donor bone marrow-derived dendritic cells Transplant Proc 2008:40:3711-3.

30 Li R, Zheng X, Popov I, et al. Gene silencing of IL-12 in dendritic cells inhibits autoimmune arthritis. J Trans/ Med 2012:10:19.

31 Lu L, Gambotto A, Lee WC, et al. Adenoviral delivery of CTLA4Ig into myeloid dendritic cells promotes their in vitro tolerogenicity and survival in allogeneic recipients. Gene Ther 1999;6:554-63.

32 Kim SH, Kim S, Evans CH, et al. Effective treatment of established murine collageninduced arthritis by systemic administration of dendritic cells genetically modified to express IL-4. J Immunol 2001;166:3499-505.

33 Morita Y, Yang J, Gupta R, et al. Dendritic cells genetically engineered to express IL-4 inhibit murine collagen-induced arthritis. J Clin Invest 2001;107:1275-84.

34 Coates PT, Krishnan R, Kireta S, et al. Human myeloid dendritic cells transduced with an adenoviral interleukin-10 gene construct inhibit human skin graft rejection in humanized NOD-scid chimeric mice. Gene Ther 2001;8:1224-33.

35 Tan PH, Yates JB, Xue SA, et al. Creation of tolerogenic human dendritic cells via intracellular CTLA4: a novel strategy with potential in clinical immunosuppression. Blood 2005; 106:2936-43.

36 Anderson $A E$, Sayers BL, Haniffa MA, et al. Differential regulation of naive and memory CD4+ T cells by alternatively activated dendritic cells. J Leukoc Biol 2008;84:124-33

37 Anderson AE, Swan DJ, Wong OY, et al. Tolerogenic dendritic cells generated with dexamethasone and vitamin D3 regulate rheumatoid arthritis CD4 ${ }^{+} \mathrm{T}$ cells partly via transforming growth factor- $\beta 1$. Clin Exp Immunol 2017;187:113-23.

38 Steinbrink K, Wölfl M, Jonuleit $H$, et al. Induction of tolerance by IL-10-treated dendritic cells. J Immunol 1997;159:4772-80.

39 Yarilin D, Duan R, Huang YM, et al. Dendritic cells exposed in vitro to TGF-beta1 ameliorate experimental autoimmune myasthenia gravis. Clin Exp Immunol 2002;127:214-9.

40 Boks MA, Kager-Groenland JR, Haasjes MS, et al. IL-10-generated tolerogenic dendritic cells are optimal for functional regulatory $T$ cell induction--a comparative study of human clinical-applicable DC. Clin Immunol 2012;142:332-42.

41 Salazar L, Aravena O, Abello P, et al. Modulation of established murine collageninduced arthritis by a single inoculation of short-term lipopolysaccharide-stimulated dendritic cells. Ann Rheum Dis 2008:67:1235-41.

42 Hilkens CM, Isaacs JD, Thomson AW. Development of dendritic cell-based immunotherapy for autoimmunity. Int Rev Immunol 2010;29:156-83.

43 Hall BM, Pearce NW, Gurley KE, et al. Specific unresponsiveness in rats with prolonged cardiac allograft survival after treatment with cyclosporine. III. Further characterization of the CD4+ suppressor cell and its mechanisms of action. J Exp Med 1990;171:141-57

44 Sakaguchi S, Sakaguchi N, Asano M, et al. Immunologic self-tolerance maintained by activated $T$ cells expressing IL-2 receptor alpha-chains (CD25). Breakdown of a single mechanism of self-tolerance causes various autoimmune diseases. J Immunol 1995; 155:1151-64

45 Sakaguchi S, Wing K, Onishi Y, et al. Regulatory T cells: how do they suppress immune responses? Int Immunol 2009;21:1105-11.

46 Waldmann $\mathrm{H}$, Hilbrands $\mathrm{R}$, Howie $\mathrm{D}$, et al. Harnessing FOXP3 + regulatory T cells for transplantation tolerance. J Clin Invest 2014;124:1439-45.

47 Lawson CA, Brown AK, Bejarano V, et al. Early rheumatoid arthritis is associated with a deficit in the $C D 4+C D 25$ high regulatory $T$ cell population in peripheral blood. Rheumatology 2006;45:1210-7.

48 Tang Q, Adams JY, Penaranda C, et al. Central role of defective interleukin-2 production in the triggering of islet autoimmune destruction. Immunity 2008:28:687-97.

49 Putnam AL, Brusko TM, Lee MR, et al. Expansion of human regulatory T-cells from patients with type 1 diabetes. Diabetes 2009:58:652-62.

50 Bluestone JA, Buckner JH, Fitch M, et al. Type 1 diabetes immunotherapy using polyclonal regulatory T cells. Sci Trans/ Med 2015;7:315ra189.

51 Groux H, O'Garra A, Bigler M, et al. A CD4+ T-cell subset inhibits antigen-specific T-cell responses and prevents colitis. Nature 1997:389:737-42.

52 Gregori S, Roncarolo MG. Engineered T regulatory type 1 cells for clinical application. Frontiers in Immunology 2018;9.
53 Huehn J, Hamann A. Homing to suppress: address codes for Treg migration. Trends Immunol 2005:26:632-6.

54 Anderson AE, Swan DJ, Sayers BL, et al. LPS activation is required for migratory activity and antigen presentation by tolerogenic dendritic cells. J Leukoc Biol 2009;85:243-50

55 Sordi V, Malosio ML, Marchesi F, et al. Bone marrow mesenchymal stem cells express a restricted set of functionally active chemokine receptors capable of promoting migration to pancreatic islets. Blood 2005;106:419-27.

56 Zappia E, Casazza S, Pedemonte E, et al. Mesenchymal stem cells ameliorate experimental autoimmune encephalomyelitis inducing T-cell anergy. Blood 2005; 106:1755-61.

57 Gerdoni E, Gallo B, Casazza S, et al. Mesenchymal stem cells effectively modulate pathogenic immune response in experimental autoimmune encephalomyelitis. Ann Neurol 2007;61:219-27.

58 Rafei M, Campeau PM, Aguilar-Mahecha A, et al. Mesenchymal stroma cells ameliorate experimental autoimmune encephalomyelitis by inhibiting CD4 Th17 T cells in a CC chemokine ligand 2-dependent manner. J Immunol 2009;182:5994-6002

59 Bai L, Lennon DP, Caplan Al, et al. Hepatocyte growth factor mediates mesenchymal stem cell-induced recovery in multiple sclerosis models. Nat Neurosci 2012;15:862-70

60 Luz-Crawford P, Kurte M, Bravo-Alegría J, et al. Mesenchymal stem cells generate a CD4+ CD25+ Foxp3+ regulatory T cell population during the differentiation process of Th1 and Th17 cells. Stem cell research \& therapy 2013:4:65.

61 Zhou K, Zhang H, Jin O, et al. Transplantation of human bone marrow mesenchymal stem cell ameliorates the autoimmune pathogenesis in MRL/lpr mice. Cell Mol Immunol 2008; 5:417-24

62 Gu Z, Akiyama K, Ma X, et al. Transplantation of umbilical cord mesenchymal stem cells alleviates lupus nephritis in MRL/lpr mice. Lupus 2010;19:1502-14.

63 Choi EW, Shin IS, Park SY, et al. Reversal of serologic, immunologic, and histologic dysfunction in mice with systemic lupus erythematosus by long-term serial adipose tissue-derived mesenchymal stem cell transplantation. Arthritis Rheum 2012;64:243-53.

64 Augello A, Tasso R, Negrini SM, et al. Cell therapy using allogeneic bone marrow mesenchymal stem cells prevents tissue damage in collagen-induced arthritis. Arthritis Rheum 2007:56:1175-86.

65 González MA, Gonzalez-Rey E, Rico L, et al. Treatment of experimental arthritis by inducing immune tolerance with human adipose-derived mesenchymal stem cells. Arthritis Rheum 2009;60:1006-19.

66 Papadopoulou A, Yiangou M, Athanasiou E, et al. Mesenchymal stem cells are conditionally therapeutic in preclinical models of rheumatoid arthritis. Ann Rheum Dis 2012:71:1733-40.

67 Karussis D, Karageorgiou C, Vaknin-Dembinsky A, et al. Safety and immunological effects of mesenchymal stem cell transplantation in patients with multiple sclerosis and amyotrophic lateral sclerosis. Arch Neuro/ 2010:67:1187-94.

68 Bonab MM, Sahraian MA, Aghsaie A, et al. Autologous mesenchymal stem cell therapy in progressive multiple sclerosis: an open label study. Curr Stem Cell Res Ther 2012;7:407-14.

69 Connick P, Kolappan M, Crawley C, et al. Autologous mesenchymal stem cells for the treatment of secondary progressive multiple sclerosis: an open-label phase 2a proofof-concept study. Lancet Neurol 2012:11:150-6.

70 Li JF, Zhang DJ, Geng T, et al. The potential of human umbilical cord-derived mesenchymal stem cells as a novel cellular therapy for multiple sclerosis. Cell Transplant 2014;23(Suppl 1):S113-22.

71 Lublin FD, Bowen JD, Huddlestone J, et al. Human placenta-derived cells (PDA-001) for the treatment of adults with multiple sclerosis: a randomized, placebo-controlled, multiple-dose study. Mult Scler Relat Disord 2014:3:696-704.

72 Wang L, Wang L, Cong $X$, et al. Human umbilical cord mesenchymal stem cell therapy for patients with active rheumatoid arthritis: safety and efficacy. Stem Cells Dev 2013;22:3192-202.

73 Álvaro-Gracia JM, Jover JA, García-Vicuña R, et al. Intravenous administration of expanded allogeneic adipose-derived mesenchymal stem cells in refractory rheumatoid arthritis (Cx611): results of a multicentre, dose escalation, randomised, single-blind, placebo-controlled phase Ib/lla clinical trial. Ann Rheum Dis 2017;76:196-202

74 Sun L, Akiyama K, Zhang H, et al. Mesenchymal stem cell transplantation reverses multiorgan dysfunction in systemic lupus erythematosus mice and humans. Stem Cells 2009:27:1421-32.

75 Liang J, Zhang H, Hua B, et al. Allogenic mesenchymal stem cells transplantation in refractory systemic lupus erythematosus: a pilot clinical study. Ann Rheum Dis 2010;69:1423-9.

76 Sun L, Wang D, Liang J, et al. Umbilical cord mesenchymal stem cell transplantation in severe and refractory systemic lupus erythematosus. Arthritis Rheum 2010;62:2467-75

77 Wang D, Akiyama K, Zhang H, et al. Double allogenic mesenchymal stem cells transplantations could not enhance therapeutic effect compared with single 
transplantation in systemic lupus erythematosus. Clinical and Developmental Immunology 2012;2012:1-7.

78 Li X, Wang D, Liang J, et al. Mesenchymal SCT ameliorates refractory cytopenia in patients with systemic lupus erythematosus. Bone Marrow Transplant 2013;48:544-50

79 Wang D, Zhang $\mathrm{H}$, Liang J, et al. Allogeneic mesenchymal stem cell transplantation in severe and refractory systemic lupus erythematosus: 4 years of experience. Cell Transplant 2013:22:2267-77.

80 Wang D, Li J, Zhang Y, et al. Umbilical cord mesenchymal stem cell transplantation in active and refractory systemic lupus erythematosus: a multicenter clinical study. Arthritis Res Ther 2014;16:R79.

81 Shi D, Wang D, Li X, et al. Allogeneic transplantation of umbilical cord-derived mesenchymal stem cells for diffuse alveolar hemorrhage in systemic lupus erythematosus. Clin Rheumatol 2012;31:841-6.

82 García-Olmo D, García-Arranz M, Herreros D, et al. A phase I clinical trial of the treatment of Crohn's fistula by adipose mesenchymal stem cell transplantation. Dis Colon Rectum 2005:48:1416-23.

83 Garcia-Olmo D, Herreros D, Pascual I, et al. Expanded adipose-derived stem cells for the treatment of complex perianal fistula: a phase II clinical trial. Dis Colon Rectum 2009;52:79-86.

84 Duijvestein M, Vos AC, Roelofs $\mathrm{H}$, et al. Autologous bone marrow-derived mesenchymal stromal cell treatment for refractory luminal Crohn's disease: results of a phase I study. Gut 2010;59:1662-9.

85 Ciccocioppo R, Bernardo ME, Sgarella A, et al. Autologous bone marrow-derived mesenchymal stromal cells in the treatment of fistulising Crohn's disease. Gut 2011;60:788-98.

86 Liang J, Zhang H, Wang D, et al. Allogeneic mesenchymal stem cell transplantation in seven patients with refractory inflammatory bowel disease. Gut 2012;61:468-9.

87 de la Portilla F, Alba F, García-Olmo D, et al. Expanded allogeneic adipose-derived stem cells (eASCs) for the treatment of complex perianal fistula in Crohn's disease: results from a multicenter phase I/lla clinical trial. Int J Colorectal Dis 2013:28:313-23

88 Forbes GM, Sturm MJ, Leong RW, et al. A phase 2 study of allogeneic mesenchymal stromal cells for luminal Crohn's disease refractory to biologic therapy. Clin Gastroenterol Hepatol 2014;12:64-71.

89 Molendijk I, Bonsing BA, Roelofs H, et al. Allogeneic bone marrow-derived mesenchymal stromal cells promote healing of refractory perianal fistulas in patients with crohn's disease. Gastroenterology 2015;149:918-27.

90 Panés J, García-Olmo D, Van Assche G, et al. Expanded allogeneic adipose-derived mesenchymal stem cells (Cx601) for complex perianal fistulas in Crohn's disease: a phase 3 randomised, double-blind controlled trial. Lancet 2016;388:1281-90.

91 Dietz AB, Dozois EJ, Fletcher JG, et al. Autologous mesenchymal stem cells, applied in a bioabsorbable matrix, for treatment of perianal fistulas in patients with crohn's disease. Gastroenterology 2017;153:59-62.

92 Le Blanc K, Frassoni F, Ball L, et al. Mesenchymal stem cells for treatment of steroid-resistant, severe, acute graft-versus-host disease: a phase II study. Lancet 2008:371:1579-86

93 Gao L, Zhang Y, Hu B, et al. Phase II multicenter, randomized, double-blind controlled study of efficacy and safety of umbilical cord-derived mesenchymal stromal cells in the prophylaxis of chronic graft-versus-host disease after HLA-haploidentical stemcell transplantation. J Clin Oncol 2016:34:2843-50.

94 Clare-Salzler MJ, Brooks J, Chai A, et al. Prevention of diabetes in nonobese diabetic mice by dendritic cell transfer. J Clin Invest 1992;90:741-8.

$95 \mathrm{Ma}$ L, Qian S, Liang X, et al. Prevention of diabetes in NOD mice by administration of dendritic cells deficient in nuclear transcription factor-kappaB activity. Diabetes 2003:52:1976-85.

96 Creusot RJ, Yaghoubi SS, Kodama K, et al. Tissue-targeted therapy of autoimmune diabetes using dendritic cells transduced to express IL-4 in NOD mice. Clin Immunol 2008;127:176-87.

97 Martin E, Capini C, Duggan E, et al. Antigen-specific suppression of established arthritis in mice by dendritic cells deficient in NF-KB. Arthritis \& Rheumatism 2007:56:2255-66

98 Li Y, Chu N, Rostami A, et al. Dendritic cells transduced with SOCS-3 exhibit a tolerogenic/DC2 phenotype that directs type 2 Th cell differentiation in vitro and in vivo. J Immunol 2006;177:1679-88.

99 Huang YM, Yang JS, Xu LY, et al. Autoantigen-pulsed dendritic cells induce tolerance to experimental allergic encephalomyelitis (EAE) in Lewis rats. Clin Exp Immunol 2000;122:437-44.

100 Verginis P, Li HS, Carayanniotis G. Tolerogenic semimature dendritic cells suppress experimental autoimmune thyroiditis by activation of thyroglobulin-specific CD4+CD25+ T cells. J Immunol 2005:174:7433-9.

101 Giannoukakis N, Phillips B, Finegold D, et al. Phase I (safety) study of autologous tolerogenic dendritic cells in type 1 diabetic patients. Diabetes Care 2011:34:2026-32.

102 Jauregui-Amezaga A, Cabezón R, Ramírez-Morros A, et al. Intraperitoneal administration of autologous tolerogenic dendritic cells for refractory crohn's disease: a phase I study. J Crohns Colitis 2015;9:1071-8.
103 Bell GM, Anderson AE, Diboll J, et al. Autologous tolerogenic dendritic cells for rheumatoid and inflammatory arthritis. Ann Rheum Dis 2017:76:227-34.

104 Benham H, Nel HJ, Law SC, et al. Citrullinated peptide dendritic cell immunotherapy in HLA risk genotype-positive rheumatoid arthritis patients. Sci Trans/ Med 2015;7:ra87.

105 Joo YB, Park J-E, Choi C-B. Phase 1 Study of immunotherapy using autoantigenloaded dendritic cells in patients with anti-citrullinated peptide antigen positive rheumatoid arthritis. ACR/ARHP Annual Meeting 2014.

106 Hutchinson JA, Roelen D, Riquelme P, et al. Preoperative treatment of a presensitized kidney transplant recipient with donor-derived transplant acceptance-inducing cells. Transpl Int 2008;21:808-13.

107 Hutchinson JA, Gövert F, Riquelme P, et al. Administration of donor-derived transplant acceptance-inducing cells to the recipients of renal transplants from deceased donors is technically feasible. Clin Transplant 2009;23:140-5.

108 Hutchinson JA, Riquelme P, Sawitzki B, et al. Cutting Edge: Immunological consequences and trafficking of human regulatory macrophages administered to renal transplant recipients. The Journal of Immunology 2011;187:2072-8.

109 Obermajer N, Kalinski P. Generation of myeloid-derived suppressor cells using prostaglandin E2. Transplant Res 2012;1:15.

110 Eggenhofer E, Hoogduijn MJ. Mesenchymal stem cell-educated macrophages. Transplant Res 2012:1:12.

111 Sagoo P, Perucha E, Sawitzki B, et al. Development of a cross-platform biomarker signature to detect renal transplant tolerance in humans. J Clin Invest 2010;120:1848-61.

112 Miyara M, Gorochov G, Ehrenstein M, et al. Human FoxP3+ regulatory T cells in systemic autoimmune diseases. Autoimmun Rev 2011;10:744-55.

113 Yeh WI, Seay HR, Newby B, et al. Avidity and bystander suppressive capacity of human regulatory T cells expressing De Novo autoreactive T-cell receptors in type 1 diabetes. Front Immunol 2017:8:1313

114 Tang Q, Henriksen KJ, Bi M, et al. In vitro-expanded antigen-specific regulatory T cells suppress autoimmune diabetes. J Exp Med 2004;199:1455-65.

115 Tarbell KV, Yamazaki S, Olson K, et al. CD25+ CD4+ T cells, expanded with dendritic cells presenting a single autoantigenic peptide, suppress autoimmune diabetes. J Exp Med 2004:199:1467-77.

116 Masteller EL, Warner MR, Tang Q, et al. Expansion of functional endogenous antigen-specific CD4+CD25+ regulatory T cells from nonobese diabetic mice. J Immunol 2005;175:3053-9.

117 Yamazaki S, Inaba K, Tarbell KV, et al. Dendritic cells expand antigen-specific Foxp3+ CD25+ CD4+ regulatory T cells including suppressors of alloreactivity. Immunol Rev 2006:212:314-29.

118 Tarbell KV, Yamazaki S, Steinman RM. The interactions of dendritic cells with antigen-specific, regulatory T cells that suppress autoimmunity. Semin Immunol 2006;18:93-102.

119 Brunstein CG, Miller JS, Cao Q, et al. Infusion of ex vivo expanded T regulatory cells in adults transplanted with umbilical cord blood: safety profile and detection kinetics. Blood 2011:117:1061-70.

120 Di lanni M, Falzetti F, Carotti A, et al. Tregs prevent GVHD and promote immune reconstitution in HLA-haploidentical transplantation. Blood 2011:117:3921-8.

121 Marek-Trzonkowska N, Myśliwiec M, Dobyszuk A, et al. Administration of CD4+CD25highCD127- regulatory T cells preserves $\beta$-cell function in type 1 diabetes in children. Diabetes Care 2012;35:1817-20

122 Marek-Trzonkowska N, Myśliwiec M, Dobyszuk A, et al. Therapy of type 1 diabetes with CD4(+)CD25(high)CD127-regulatory T cells prolongs survival of pancreatic islets - results of one year follow-up. Clin Immunol 2014:153:23-30.

123 Desreumaux P, Foussat A, Allez M, et al. Safety and efficacy of antigenspecific regulatory T-cell therapy for patients with refractory Crohn's disease. Gastroenterology 2012;143:1207-17.

124 Zhou X, Bailey-Bucktrout SL, Jeker LT, et al. Instability of the transcription factor Foxp3 leads to the generation of pathogenic memory T cells in vivo. Nat Immunol 2009;10:1000-7.

125 Zhou X, Bailey-Bucktrout S, Jeker LT, et al. Plasticity of CD4(+) FoxP3(+) T cells. Curr Opin Immunol 2009;21:281-5.

126 Hoffmann P, Boeld TJ, Eder R, et al. Loss of FOXP3 expression in natural human CD4+CD25+ regulatory T cells upon repetitive in vitro stimulation. Eur J Immunol 2009:39:1088-97.

127 Schmidl C, Hansmann L, Andreesen R, et al. Epigenetic reprogramming of the RORC locus during in vitro expansion is a distinctive feature of human memory but not naïve Treg. Eur J Immunol 2011;41:1491-8

128 Tartar DM, VanMorlan AM, Wan X, et al. FoxP3+RORgammat+ T helper intermediates display suppressive function against autoimmune diabetes. I Immunol 2010;184:3377-85.

129 Beyer M, Schumak B, Weihrauch MR, et al. In vivo expansion of naïve CD4+ CD25(high) FOXP3+ regulatory T cells in patients with colorectal carcinoma after IL-2 administration. PLoS One 2012:7:e30422.

130 Lemoine FM, Cherai M, Giverne C, et al. Massive expansion of regulatory T-cells following interleukin 2 treatment during a phase I-II dendritic cell-based immunotherapy of metastatic renal cancer. Int J Oncol 2009;35:569-81. 
131 Bjoern J, Brimnes MK, Andersen MH, et al. Changes in peripheral blood level of regulatory $T$ cells in patients with malignant melanoma during treatment with dendritic cell vaccination and low-dose IL-2. Scand J Immunol 2011;73:222-33.

132 Koreth J, Matsuoka K, Kim HT, et al. Interleukin-2 and regulatory T cells in graftversus-host disease. N Engl J Med 2011;365:2055-66.

133 Kennedy-Nasser AA, Ku S, Castillo-Caro P, et al. Ultra low-dose IL-2 for GVHD prophylaxis after allogeneic hematopoietic stem cell transplantation mediates expansion of regulatory $T$ cells without diminishing antiviral and antileukemic activity. Clin Cancer Res 2014;20:2215-25.

134 Saadoun D, Rosenzwajg M, Joly F, et al. Regulatory T-cell responses to low-dose interleukin-2 in HCV-induced vasculitis. N Eng/ J Med 2011;365:2067-77.

135 Long SA, Rieck M, Sanda S, et al. Rapamycin/IL-2 combination therapy in patients with type 1 diabetes augments Tregs yet transiently impairs $\beta$-cell function. Diabetes 2012;61:2340-8.

136 von Spee-Mayer C, Siegert E, Abdirama D, et al. Low-dose interleukin-2 selectively corrects regulatory T cell defects in patients with systemic lupus erythematosus. Ann Rheum Dis 2016;75:1407-15.

137 Humrich JY, von Spee-Mayer C, Siegert E, et al. Rapid induction of clinical remission by low-dose interleukin-2 in a patient with refractory SLE. Ann Rheum Dis 2015;74:791-2.

138 He J, Zhang $X$, Wei Y, et al. Low-dose interleukin-2 treatment selectively modulates CD4(+) T cell subsets in patients with systemic lupus erythematosus. Nat Med 2016;22:991-3.

139 Rosenzwajg M, Churlaud G, Mallone R, et al. Low-dose interleukin-2 fosters a dose-dependent regulatory T cell tuned milieu in T1D patients. J Autoimmun 2015;58:48-58.

140 Todd JA, Evangelou M, Cutler AJ, et al. Regulatory T cell responses in participants with type 1 diabetes after a single dose of interleukin-2: a non-randomised, open label, adaptive dose-finding trial. PLoS Med 2016;13:e1002139.

141 Truman LA, Pekalski ML, Kareclas P, et al. Protocol of the adaptive study of IL-2 dose frequency on regulatory T cells in type 1 diabetes (DILfrequency): a mechanistic, non-randomised, repeat dose, open-label, response-adaptive study. BMJ Open 2015; 5:e009799.

142 Seelig E, Howlett J, Porter L, et al. Targeting regulatory T cells with Interleukin-2 treatment in type 1 diabetes: a response-adaptive, non-randomised, open-label trial of repeat doses of Aldesleukin (DILfrequency). bioRxiv 2017.

143 Orban T, Farkas K, Jalahej H, et al. Autoantigen-specific regulatory T cells induced in patients with type 1 diabetes mellitus by insulin B-chain immunotherapy. J Autoimmun 2010;34:408-15.

144 Lund ME, O'Brien BA, Hutchinson AT, et al. Secreted proteins from the helminth Fasciola hepatica inhibit the initiation of autoreactive $T$ cell responses and prevent diabetes in the NOD mouse. PLoS One 2014;9:e86289.
145 Zaccone P, Cooke A. Vaccine against autoimmune disease: can helminths or their products provide a therapy? Curr Opin Immunol 2013;25:418-23.

146 Kahl J, Brattig N, Liebau E. The untapped pharmacopeic potential of helminths. Trends Parasitol 2018;34:828-42.

147 Siepert A, Brösel S, Vogt K, et al. Mechanisms and rescue strategies of calcineurin inhibitor mediated tolerance abrogation induced by anti-CD4 mAb treatment. Am J Transplant 2013;13:2308-21.

148 Snir O, Rieck M, Gebe JA, et al. Identification and functional characterization of T cells reactive to citrullinated vimentin in $\mathrm{HLA}-\mathrm{DRB} 1{ }^{*} 0401$-positive humanized mice and rheumatoid arthritis patients. Arthritis Rheum 2011;63:2873-83.

149 Hansson M, Mathsson L, Schlederer T, et al. Validation of a multiplex chip-based assay for the detection of autoantibodies against citrullinated peptides. Arthritis Res Ther 2012;14:R201.

150 Phillips BE, Garciafigueroa Y, Trucco M, et al. Clinical tolerogenic dendritic cells: exploring therapeutic impact on human autoimmune disease. Front Immunol 2017;8:1279.

151 FDA U. Final guidance for industry. Potency tests for cellular and gene therapy products. USA: US Department of health and human services R, 2011: 1-19.

152 Hanley PJ, Mei Z, Durett AG, et al. Efficient manufacturing of therapeutic mesenchymal stromal cells with the use of the Quantum Cell Expansion System. Cytotherapy 2014;16:1048-58.

153 Dwarshuis NJ, Parratt K, Santiago-Miranda A, et al. Cells as advanced therapeutics: State-of-the-art, challenges, and opportunities in large scale biomanufacturing of high-quality cells for adoptive immunotherapies. Adv Drug Deliv Rev 2017;114(Suppl C):222-39.

154 Gitelman SE, Bluestone JA. Regulatory T cell therapy for type 1 diabetes: may the force be with you. J Autoimmun 2016;71:78-87.

155 Geissler EK. The ONE Study compares cell therapy products in organ transplantation: introduction to a review series on suppressive monocyte-derived cells. Transplant Res 2012;1:11.

156 Kendal AR, Waldmann H. Infectious tolerance: therapeutic potential. Curr Opin Immunol 2010;22:560-5.

157 Chandrasekharan D, Issa F, Wood KJ. Achieving operational tolerance in transplantation: how can lessons from the clinic inform research directions? Transpl Int 2013;26:576-89.

158 Hartemann A, Bensimon G, Payan CA, et al. Low-dose interleukin 2 in patients with type 1 diabetes: a phase 1/2 randomised, double-blind, placebo-controlled trial. Lancet Diabetes Endocrinol 2013;1:295-305.

159 Castela E, Le Duff F, Butori C, et al. Effects of low-dose recombinant interleukin 2 to promote T-regulatory cells in alopecia areata. JAMA Dermatol 2014;150:748-51. 